\title{
CLASSICAL AND CONTEMPORARY FIQH APPROACHES TO RE-ESTIMATING THE ZAKAT POTENTIAL IN INDONESIA
}

\author{
Maya Asfarina ${ }^{1}$, Ascarya $^{2}$ and Irfan Syauqi Beik ${ }^{3}$ \\ ${ }^{1}$ STEI TAZKIA, Indonesia, mayasfarina@gmail.com \\ ${ }^{2}$ Bank Indonesia, Indonesia, ascarya@yahoo.com \\ ${ }^{3}$ IPB University, Indonesia, irfan_beik@ipb.ac.id
}

\begin{abstract}
This study aims to re-estimate the potential of zakat in Indonesia based on the classical and contemporary fiqh approaches, as well as including optimistic and realistic scenarios with different assumptions. Under the classical fiqh approach, the potential amount of zakat was calculated based on the zakatable assets that have been agreed upon by all scholars, including only zakat on savings. Meanwhile, using the contemporary fiqh approach, the zakat potential was calculated based on a new classification of zakatable assets agreed by contemporary scholars after considering the issue of economic development, including professional (household) zakat, corporate zakat and zakat on savings. The results show that, based on the classical figh approach, the potential zakat amount is IDR 69.57 trillion, or equivalent to $0.56 \%$ of GDP under the optimistic scenario, and it is IDR 13.26 trillion, or equivalent to $0.11 \%$ of GDP, under the realistic scenario. Meanwhile, based on the contemporary fiqh approach, the potential zakat amount is IDR 216.54 trillion, or equivalent to $1.75 \%$ of GDP, under the optimistic scenario, and it is IDR 74.87 trillion, or equivalent to $0.60 \%$ of GDP, under the realistic scenario. The estimated zakat potentials are still significantly higher than actual zakat collection recorded. However, the results of classical approach under the realistic scenario $(0.11 \%$ of GDP) is the closest to the real 2018 zakat collection of $0.05 \%$ of GDP, which could be the indication that most Indonesian Muslims follow classical fiqh approach in calculating their zakat maal obligation.
\end{abstract}

Keywords: Zakat Potential, Classical Figh, Contemporary Fiqh.

JEL Classification: C13; L30; P4.

\author{
Article history: \\ Received : May 14, 2019 \\ Revised : : June 02, 2019 \\ Accepted : June 04, 2019 \\ Available online : July 30, 2019
}

https://doi.org/10.21098/jimf.v5i2.1068 


\section{INTRODUCTION}

\subsection{Background}

The term zakat means clean, pure, growing, developing, and increasing, in both a metaphoric and spiritual sense. The real-life practice of zakat is defined as giving a portion of the accumulated assets that one holds, according to the nishab (threshold) and haul (time period) after basic needs have been fulfilled and debt has been paid (Qardhawi, 1991).

From Abu Abdirrahman Abdullah bin Umar bin Al-Khattab radhiyallahu'anhuma I heard the Prophet shalallahu'alaihi wassalam said 'Islam is built on five (pillars): testifying (the fact) that there is no god but Allah, that Muhammad is His messenger and the establishment of prayer, payment of Zakat, Pilgrimage to the House (Ka'ba) and the fast of Ramadan (Narrated by Muslim, Number 19).

In Islam, zakat is an obligation for Muslims. Al-Qur'an states that zakat can purify and bring peace. Zakat is collected, and Muslims give excess assets to the poor and other groups, as stated in the Qur'an at-Taubah verse 60. For Muslims, paying zakat is a form of obedience to Allah's commands. Zakat is a sign of the greatness of Allah as well as proof of the faith of His servants. Zakat also delivers benefits to His fellow creatures. Some of these are economic benefits since zakat can reduce poverty (Hasan, 2010).

Various official reports state that there has been a fall in the poverty rate, yet the number of poor people is still significant due to the fact that development has thus far failed to tackle the issue of welfare inequality (Saleh, 2013). Therefore, zakat can help in achieving the government's goal of improving people's welfare (Ibrahim, 2015). In addition, the provision of zakat funds for small and medium enterprises through business guidance will serve to nurture entrepreneurs, who would hopefully improve the future economy (Hoque et. al., 2015).

Although developed countries have many entrepreneurs, significant amounts of capital are required to start a business. Unfortunately, budding entrepreneurs often end up taking out damaging interest-based loans. Zakat is able to reduce the number of such loans, not only because the charging of interest (usury) is forbidden by Islamic law, but also because interest is one of the causes of poverty (Mohsin, 2013). Thus, zakat can increase the standard of living of recipients in that they have better opportunities and quality of life, with one of the indicators being compliance with paying zakat itself (Beik \& Arsyianti, 2015). More broadly, viewed from the macroeconomic perspective, zakat can also be a benchmark for economic growth (Sarea, 2012). Zakat can even become a solution for building a stable and crisis-resistant economy (Ascarya, 2017).

Based on data from Statistics Indonesia (BPS) in 2010, the Indonesian population reached 237 million people, 207 million of whom, or around $83 \%$, was Muslim. In 2011, BAZNAS published figures revealing the potential amount of zakat to be IDR 217 trillion, or 3.40\% of GDP. Based on the size of the Muslim population in Indonesia, it would be possible to achieve this potential amount through payments of only around IDR $87,000-100,000$ per person. 
Table 1.

Collection of National Zakat Funds (IDR)

\begin{tabular}{lcc}
\hline Year & Zakat Collection & Percentage of GDP \\
\hline 2015 & 2.36 trillion & 0.01 \\
2016 & 3.73 trillion & 0.02 \\
2017 & 4.19 trillion & 0.03 \\
2018 & 8.10 trillion & 0.05 \\
\hline
\end{tabular}

Source: Zakat Statistics, BAZNAS

Therefore, while the potential amount of zakat in 2011 was IDR 217 trillion, or $3.40 \%$ of GDP, BAZNAS Zakat Statistics shows that the actual amounts of zakat collected in the three-year period 2015-2018 stood at only $0.01 \%, 0.02 \%, 0.03 \%$ and $0.05 \%$ of GDP for the three respective years. Furthermore, existing studies, including UIN Syarif Hidatullah (2005), PIRAC (2007), IDB (undated), Firdaus et al. (2012) and Wibisono (2015) found diverse results of Indonesia's zakat potentials, due to differences in their approaches, proxies and calculation methods. Therefore, there is a need to re-estimate the zakat potential in Indonesia using various fiqh approaches, as well as better proxies and calculation method.

\subsection{Objective}

This study aims to re-estimate the potential of zakat in Indonesia using contemporary and classical figh approaches, each with optimistic and realistic scenarios. This study will be based on Firdaus et al. (2012), and will modify the method of calculation to incorporate new data and new proxies.

\subsection{Problem Limitation}

The type of zakat to be addressed in this study is zakat maal, as referred to in Law No. 23 of 2011 concerning Zakat Management. The following variables are included in zakat maal: 1) following the classical fiqh approach, the zakatable assets of individual muzakki include zakat on savings; and 2) following the contemporary fiqh approach, the zakatable assets of individual muzakki include professional (household) zakat, corporate zakat, and zakat on savings.

\section{LITERATURE REVIEW}

\subsection{An Overview of Zakat}

According to Samad and Glenn (2010), the history of zakat can be traced back to the period from Prophet Adam 'alayhissalam (peace be upon him) up to Prophet 'Isa 'alayhissalam (peace be upon him), when there was a $10 \%$ increase in the value of annual assets to be paid known as tithe. At the birth of Islam in Mecca, Allah commanded the rich to feed the poor by providing a portion of sustenance, ensuring the rights of the poor and needy, and commanding the rich to pay zakat, although the amount to be paid had yet to be set (Qardhawi, 1991). The vast majority of Muslim scholars held the opinion that zakat collection was first carried 
out during the Medina period in the second year of the Hijrah. The collection of zakat was initially carried out and managed directly by the Prophet Muhammad shalallahu 'alaihi wassalam (peace and blessings be upon him), whereby the collection and management elements were centralized and handled entirely through Baytul Ma'1. From the beginnings of zakat collection, which started from the second year of Hijrah, Rasulullah shalallahu 'alaihi wassalam acted directly as the zakat manager. Rasulullah shalallahu 'alaihi wassalam then appointed professional zakat collectors to be managed by zakat officials for the purpose of collecting and distributing zakat amounts in the areas where they were collected. The management of zakat thus underwent a transformation, from originally being managed directly by Rasulullah shalallahu 'alaihi wassalam, to a more structured and organized form of management (Wibisono, 2015).

Zakat is a special form of worship as it reflects not only the relationship between human beings and God but also with others. Zakat may also bring social and economic impacts on societies. Choudhury and Harahap (2008) stated that Islamic banks have reciprocal relationships with zakat and the economy at large. As such, Islamic banks direct zakat funds to government projects involved in tackling poverty. Islamic bank financing also includes participation in the development of financing instruments. Zakat can be targeted at specific economic sectors; as such, zakat funds can be directed to the consumption sector, investment sector, or government expenditure sector, based on the involvement of zakat funds in the production activities needed by those sectors. Abdullah, Derus, and Al-Malkawi (2014) stated that zakat is proven very effective in helping to lift poor people out of poverty. Poor people in rural areas whose standard of living falls far below decent levels accept Zakat.

Estimates of the amount of zakat to be collected in the next period are important for evaluating its management. Solving the problem requires good management, great effort, and the full support of all parties involved, such as zakat agencies, universities, schools, and the government. The gap between the optimal amount of zakat that could be collected and the amount actually collected is due to the absence of any sanctions for non-zakat-paying muzakki (Parisi, 2017). Various measures can be adopted in an effort to increase the amount of zakat collected. These include the development of quality services for zakat institutions (Wahab, Zainol, \& Bakar, 2017), combining zakat with charity products and sponsorship program support, and others (Kashif, Jamal, \& Rehman, 2016), along with important variables such as the relationship between benefits, suitability, visible results, the ability to experiment, proven results, complexity, picture, weakness and trust (Yusuf \& Derus, 2013), technological improvements and equipment capital (Djaghballou, Djaghballou, Larbani, \& Mohamad, 2017), and zakat incentives as a tax deduction (Obaidullah,2014).

Javaid and Al-Malkawi (2017) stated that zakat makes a positive contribution to profit and value and can be considered a strategic solution to maximizing profits and improving performance. It is also essential that the various strategies for improving the performance of zakat institutions are supported by good risk management for the continuity of zakat institutions in that they can be managed professionally, which includes the case of social institutions (Ascarya, et al., 2018). 
Despite the many benefits and virtues of zakat in terms of both faith and society, zakatable assets must also meet certain conditions (Qardhawi, 1991); as such, they must be:

1. Fully Owned

2. Developing

3. Reaching Nishab

4. Above the usual needs

5. Free from debt

6. Reaching one lunar year.

\subsection{Estimated Zakat Potential}

In order to estimate the potential amounts of zakat, this study uses two approaches to zakatable assets, which are based on the classical fiqh and contemporary fiqh approaches. The classical fiqh approach classifies zakatable assets according to the consensus among most Islamic scholars, that is, zakat on agricultural products, livestock, gold and silver, as well as trade and mining.

The contemporary fiqh approach proposes adjusting the zakatable assets by taking into account the factor of economic development, thus bringing in new classifications of zakatable assets, which, as argued by the proponents of the approach, share the same characteristics as zakatable assets according to classical fiqh: the developing nature of such assets. However, the classifications of new zakatable assets are yet to be agreed upon by most Islamic scholars. The following zakatable assets are differentiated based on the two fiqh approaches (Sarwat, 2016).

Table 2.

Zakatable Assets Based on The Classical and Contemporary Fiqh Approaches

\begin{tabular}{|c|c|c|}
\hline No. & $\begin{array}{l}\text { Zakatable Assets Based on The } \\
\text { Classical Fiqh Approach }\end{array}$ & $\begin{array}{l}\text { Zakatable Assets Based on The Contemporary Fiqh } \\
\text { Approach }\end{array}$ \\
\hline 1 & Zakat on Agricultural Products & Zakat on Cash \\
\hline 2 & Zakat on Livestock & Professional Zakat \\
\hline 3 & Zakat on Gold and Silver & Corporate zakat \\
\hline 4 & Zakat on Commercial Goods & Zakat on Production \\
\hline 5 & Zakat Rikaz and Ma'adin & Zakah on Securities \\
\hline 6 & & Zakat on Currency Trading \\
\hline 7 & & Zakat on Investment \\
\hline 8 & & Zakat on Islamic Insurance \\
\hline 9 & & Zakah on the Modern Household Sector \\
\hline
\end{tabular}

Source: Sarwat (2016)

\subsection{Previous Studies}

Syarif Hidayatullah State Islamic University undertook initial research on the estimated potential of zakat in 2005. There, it was found that the potential amounts of zakat wealth and zakat al-Fitr (a special zakat in the holy month of Ramadan) stood at IDR 19.30 trillion, equivalent to $1.10 \%$ of GDP. In 2007, PIRAC calculated the potential of zakat wealth using data obtained from a survey of 2,000 (two 
thousand) respondents. The percentage of respondents who claimed to be muzakki served as a proxy for muzakki among the total Muslim population in Indonesia. This figure was then multiplied by the average zakat amount from the previous year to generate the zakat potential, with the result being IDR 9.09 trillion.

Firdaus et al. (2012) calculated that Indonesia's zakat potential amounted to IDR 217 trillion, equivalent to $3.40 \%$ of GDP. The results were calculated based on the potential of professional (household) zakat, corporate zakat, and zakat on savings. The potential of professional (household) zakat was calculated by multiplying the average zakat payment per household, the percentage of eligible household (muzakki), the real number of total household, and the percentage of Muslim. The potential of corporate zakat was calculated from total profits of state-owned and private-owned companies deducted by profits of non-halal stateowned and private-owned companies, such as tobacco and alcohol companies, and then multiplied it by the rate of zakat maal $2.5 \%$. Meanwhile, the potential of zakat on savings was calculated from total deposits of state-owned (national and regional) banks as well as Islamic banks, and then multiplied it by the rate of zakat maal $2.5 \%$.

Finally, Wibisono (2015) calculated the potential of zakat in 2010 by calculating zakat based on the industrial sector and reducing this amount by the various zakat rates applied to different sectors. For example, for the agricultural sector, the zakat rate is $5.00 \%-10.00 \%$ depending on the irrigation method used, while mining is subject to a zakat rate of $20.00 \%$.

Table 3.

Comparison of Zakat potential

\begin{tabular}{lccccc}
\hline No. & Reference & $\begin{array}{c}\text { Year of } \\
\text { Data }\end{array}$ & Zakat Potential & $\begin{array}{c}\text { GDP } \\
\text { Equivalent }\end{array}$ & Details \\
\hline 1 & UIN PBB (2005) & 2004 & IDR19.30trillion & $1.10 \%$ & $\begin{array}{c}\text { Zakat Al-Fitr } \\
\text { Zakaton Assets }\end{array}$ \\
\hline 2 & PIRAC (2007) & 2007 & IDR9.09 trillion & $0.46 \%$ & Household Zakat \\
\hline 3 & Firdaus et al. (2012) & 2010 & IDR217.60 trillion & $3.40 \%$ & $\begin{array}{c}\text { Household Zakat } \\
\text { Corporate Zakat } \\
\text { Zakat on Savings }\end{array}$ \\
\hline 4 & Wibisono (2015) & 2010 & IDR106.60trillion & $1.70 \%$ & Household Zakat \\
\hline Source: Authors' compilation & & & &
\end{tabular}

In 2012, Firdaus et al. (2012), the National Amil Zakat Agency published figures for Indonesia's potential national zakat: IDR217.60 trillion, or equivalent to $3.40 \%$ of GDP. However, the national statistics on zakat stated that the total zakat collection for 2016 amounted to only IDR 3 trillion, or $0.02 \%$ of GDP. Moreover, Forbes stated that of the 50 (fifty) richest people in Indonesia in 2016, only 8 (eight) were Muslim, thus equating to $16.00 \%$ being muzakki. Meanwhile, based on property ownership, from total assets of IDR 1.319 trillion, assets totaling only IDR 144 trillion were held by Muslim businessmen. This means that from the wealth of Indonesian people, the proxy for muzakki comprises only approximately $10.97 \%$ of the ownership of Muslim businessmen who are obliged to pay zakat (i.e., muzakki). 
International research states that the estimated potential of Indonesian zakat falls between $1.00 \%-2.00 \%$ of GDP. The results are divided into three categories. Based on the classical figh approach, the potential zakat amount, as a percentage of GDP, is $1.00 \%$. Taking the contemporary fiqh approach, or in this case, referring to the opinion of Yusuf Qardhawi, the result is 1.70\%. Finally, if the researcher further modifies the approach to include the value of fixed assets, the result is $2.00 \%$ of GDP.

Table 4.

Indonesia's Zakat Potential According to Monzer Kahf

\begin{tabular}{lc}
\hline \multicolumn{1}{c}{ Zakatable Assets } & Percentage of GDP \\
\hline Based on Classical Fiqh (Agriculture, Trade, and Cash) & $1.00 \%$ \\
\hline $\begin{array}{l}\text { Based on The Opinion of Yusuf Qardhawi (The object of classical fiqh zakat and } \\
\text { various types of property as the source, subject to new zakat with zakat rates of } \\
10.00 \% \text { of the net value) }\end{array}$ & $1.70 \%$ \\
\hline $\begin{array}{l}\text { Based on a Modification by Monzer Kahf (The object of classical fiqh zakat plus } \\
\text { various types of new zakah-related assets as the source, with zakat rates of 2.50\% } \\
\text { of capital plus growth) }\end{array}$ & $2.00 \%$ \\
\hline \begin{tabular}{l} 
Source: Kahf (1989) \\
\hline
\end{tabular} & \\
\hline
\end{tabular}

\section{METHODOLOGY}

\subsection{Data}

This study uses a qualitative approach to estimate the potential amounts of zakat and adopts Firdaus et al. (2012) as its main reference methodology. We used the latest figures from the Central Statistics Agency to obtain data on the number of households, the proportion of the Muslim population in each province, household income in each province, and the growth of private companies through economic census data.

The researchers also used data from the Ministry of State-Owned Enterprises for data pertaining to the profits earned by state-owned companies. Banking Statistics Data were used to obtain third-party funding data. As a proxy for Muslim-owned assets, we used the percentage of assets of the richest Muslim businessmen listed in the 2016 Forbes magazine's fifty richest people in Indonesia.

\subsection{Model Development}

This study will use Firdaus et al. (2012) as the main reference to build the new model in calculating zakat potential in Indonesia, which used contemporary fiqh approach. This study develops models using two fiqh approaches: contemporary and classical, as well as two scenarios for each approach: optimistic and realistic, resulting in four models developed to calculate zakat potential in Indonesia. Based on table 2, in this study, classical fiqh approach will include zakat on savings as the only zakatable assets, while contemporary fiqh approach will include professional (household) zakat, corporate zakat and zakat on savings. This study proposes 2 (two) alternative scenarios. First is an optimistic scenario, which assumes that all Indonesian Muslims pay zakat immediately after receiving their income, as Ibn 
Abbas proclaimed. Second is a realistic scenario, which assumes that only some eligible Indonesian Muslim or muzakki who pay the zakat. Table 5 shows the comparison of three models using contemporary figh approach.

Tabel 5.

The Comparison of Zakat Potential Calculation using Contemporary Fiqh Approach

\begin{tabular}{|c|c|c|c|}
\hline Variables & $\begin{array}{l}\text { Firdaus et al. } \\
\text { (2012) }\end{array}$ & $\begin{array}{l}\text { Contemporary } \\
\text { and Optimistic }\end{array}$ & $\begin{array}{l}\text { Contemporary } \\
\text { and Realistic }\end{array}$ \\
\hline \multicolumn{4}{|c|}{ Professional (Household) Zakat $\left(Z_{p}\right)$} \\
\hline Average Household Zakat $\left(\overline{Z_{r}}\right)$ & $\sqrt{ }$ & $\sqrt{ }$ & $\sqrt{ }$ \\
\hline Total Number of Household $\left(H_{r}\right)$ & $\sqrt{ }$ & $\sqrt{ }$ & $\sqrt{ }$ \\
\hline Percentage of Muslim $\left(M_{r}\right)$ & $\sqrt{ }$ & $\sqrt{ }$ & $\sqrt{ }$ \\
\hline Percentage of Muzakki $\left(M Z_{r}\right)$ & & & $\sqrt{ }$ \\
\hline \multicolumn{4}{|c|}{ Corporate Zakat Zakat $\left(Z_{c}\right)$} \\
\hline Corporate Profit $\left(E=E_{S T}+E_{P R}-E_{N H}\right)$ & $\sqrt{ }$ & $\sqrt{ }$ & $\sqrt{ }$ \\
\hline Zakat Rate $(2.50 \%)$ & $\sqrt{ }$ & $\sqrt{ }$ & $\sqrt{ }$ \\
\hline $\begin{array}{l}\text { Proxy of Muslim-owned Asset } \\
\left(M_{A}=10.97 \%\right)\end{array}$ & & $\sqrt{ }$ & $\sqrt{ }$ \\
\hline \multicolumn{4}{|c|}{ Zakat on Savings $\left(Z_{S}\right)$} \\
\hline State-Owned Bank $\left(S_{S B}\right)$ & $\sqrt{ }$ & $\sqrt{ }$ & \\
\hline Regional State-Owned Bank $\left(S_{R B}\right)$ & $\sqrt{ }$ & $\sqrt{ }$ & \\
\hline Islamic Bank $\left(S_{I B}\right)$ & $\sqrt{ }$ & $\sqrt{ }$ & \\
\hline All Banks $\left(S_{N B}\right)$ & & & $\sqrt{ }$ \\
\hline $\begin{array}{l}\text { Proxy of Muslim-Owned Asset } \\
\left(M_{A}=10.97 \%\right)\end{array}$ & & & $\sqrt{ }$ \\
\hline Zakat Rate $(2.50 \%)$ & $\sqrt{ }$ & $\sqrt{ }$ & $\sqrt{ }$ \\
\hline
\end{tabular}

Firdaus et al. (2012) calculated the potential of zakat using the 3 (three) types of zakat: professional (household) zakat, corporate zakat, and zakat on savings. First, the estimation for professional (household) zakat calculated average household zakat $\left.{ }^{Z_{r}}\right)$ for each province using income data per household in each province based on consumption data per household surveyed in each province and sorted according to score. The average household zakat, then multiplied by total number of household $\left(H_{r}\right)$ and percentage of Muslim $\left(M Z_{r}\right)$ to get professional (house hold) zakat for each province. The summation of all 34 province will give professional (household zakat $\left(Z_{p}\right)$. The contemporary optimistic model will use similar calculation to Firdaus et al. (2012), while the contemporary realistic model will add percentage of muzakki $\left(M Z_{R}\right)$ in the calculation.

Second, the estimation of corporate zakat $\left(Z_{C}\right)$ by Firdaus et al. (2012) included profits from state-owned company $\left(E_{S T}\right)$ and profits of private-owned company $\left(E_{P R}\right)$, deducted by profits of non-halal company $\left(E_{N H}\right)$, and then multiplied by the rate of zakat maal, $2.50 \%$. The non-halal companies are those that produce nonhalal products, such as cigarette and liquor. The contemporary optimistic and realistic models will add the proxy of Muslim-owned assets $\left(M_{A}\right)$, which is $10.97 \%$, 
in the calculation of corporate zakat $\left(Z_{C}\right)$. The proxy of $M_{A}$ is obtained by calculating the assets of 8 out of 50 richest people in Indonesia, by Forbes Magazine in 2016.

Third, the estimation of zakat on savings $\left(Z_{S}\right)$ by Firdaus et al. (2012) was performed by including deposits (third-party funds) of state-owned bank $\left(S_{S B}\right)$, regional state-owned bank $\left(S_{R B}\right)$ and Islamic bank $\left(S_{I B}\right)$, and then multiplied by the rate zakat maal, $2.50 \%$. The contemporary optimistic model will use similar calculation to Firdaus et al. (2012), while the contemporary realistic model will use deposits of all banks in Indonesia (SNB), multiplied by the proxy of Muslimowned assets $\left(M_{A}\right)$ to calculate zakat on savings $\left(Z_{S}\right)$.

Moreover, zakat potential using classical fiqh approach will only include zakat on savings $\left(Z_{S}\right)$, since classical fiqh does not recognize professional zakat as well as corporate zakat.

\subsection{Method}

Based on the four proposed models, the calculation of zakat potential in Indonesia will be based on Firdaus et al. (2012) for contemporary fiqh approach, with some modifications.

1. Estimated potential for professional (household) zakat.

This research uses a nishab (threshold) of IDR 3,825,200 per household. This figure was obtained from the BAZNAS regulation that calculates the standardized use of rice ( $524 \mathrm{~kg}$ ) and its price for that year (IDR 7,300 per $\mathrm{kg}$ ).

We use income data based on monthly consumption data per household, who has income above the nishab (threshold) in every province. The total household income above the threshold is summed up and then divided by the number of households reaching the nishab, then multiplied by 12 (twelve) months and multiplied by the zakat rate of $2.50 \%$. The result gives the value of the average potential zakat per household in each province. Therefore, the calculation of average zakat potential per household can be formulated as follows.

$$
\overline{Z_{r}}=\frac{I N_{M}}{M} \times 12 \times 2.5 \%
$$

Where $\overline{Z_{r}}$ is the average zakat payment per household in province $r ; I N_{M}$ is total monthly income of household above the nishab in that province; $M$ is total household above the nishab in that province; 12 is the number of month in a year; and $2.5 \%$ is the zakat rate of assets (maal).

The estimated potential of professional (household) zakat is obtained by calculating the average of professional (household) zakat in each province multiplied by the proportion of the Muslim population in each province and the number of real households in each province. Therefore, the calculation of professional (household) zakat with optimistic scenario can be formulated as follows.

$$
Z_{P O}=\sum_{r=1}^{34}\left(\overline{Z_{r}} x H_{r} \times M_{r}\right)
$$


Where $Z_{P O}$ is professional (household) zakat; $\overline{Z_{r}}$ is the average zakat payment per household in province $r ; H_{r}$ is total number of household in province $r$; $M_{r}$ is the percentage of Muslim in province $r$; and $r=1, \ldots, 34$ is province in Indonesia.

Meanwhile, the calculation of professional (household) zakat with realistic scenario can be formulated as follows.

$$
Z_{P R}=\sum_{r=1}^{34}\left(\overline{Z_{r}} x H_{r} x M_{r} x M Z_{r}\right)
$$

Where $M Z_{r}$ is the percentage of muzakki or eligible household with income above the nisab (threshold) in province $r$.

2. Estimated potential of corporate zakat

The estimated potential of corporate zakat is divided into 2 (two). First, the zakat potential of state-owned companies is obtained from the value of the total profit of all state-owned companies multiplied by the zakat rate of $2.5 \%$. Second, the zakat potential of private companies is derived from the profits of private companies minus companies with non-halal businesses such as cigarettes and liquor, multiplied by the zakat rate of $2.50 \%$ then multiplied by $10.97 \%$, which is assumed to be the proxy rate for Muslim-owned assets, estimated from Forbes' 50 richest people. Therefore, the calculation of corporate zakat with optimistic and realistic scenarios can be formulated as follows.

$$
Z_{C}=\left(\left(E_{S T}+\left(E_{P R} \times M_{A}\right)\right) \times 2.5 \%\right.
$$

Where $Z_{C}$ is corporate zakat; $E_{S T}$ is total profits of halal state-owned companies; $E_{P R}$ is total profits of halal private-owned companies; $\mathrm{M}_{A}$ is an estimate of Muslim-owned companies, which is $10.97 \%$; and $2.5 \%$ is the zakat rate of assets (maal).

3. Estimated potential zakat on savings

The potential of zakat on savings is calculated based on the total deposits at Government Commercial Banks (BUMN and BUMD Banks) and Sharia Banks. If the majority of Muslim communities in Indonesia save excess funds in the banks, we directly multiply the fund data from the banks by the zakat rate of $2.50 \%$. The second method, meanwhile, involves calculating the total deposits of all banks and then multiplying this by the potential muzakki, as in the calculation of corporate zakat, which is $10.97 \%$ multiplied by the zakat rate of $2.50 \%$. Therefore, the calculation of zakat on savings with optimistic scenario can be formulated as follows.

$$
Z_{S O}=\left(S_{S B}+S_{R B}+S_{I B}\right) \times 2.5 \%
$$

Where $Z_{S}$ is zakat on savings; $S_{S B}$ is total deposits of state-owned bank; $S_{R B}$ is total deposits of regional state-owned bank; $S_{I B}$ is total deposit of Islamic bank; and $2.5 \%$ is the zakat rate of assets (maal). 
Meanwhile, the calculation of zakat on savings with realistic scenario can be formulated as follows.

$$
Z_{S R}=\left(S_{N B}\right) \times 10.97 \% \times 2.5 \%
$$

Where $S_{N B}$ is total deposits of all banks in Indonesia.

Therefore, zakat potential in Indonesia $(Z)$ using contemporary fiqh approach is the summation of professional zakat, corporate zakat and zakat on savings, which can be formulated as follows.

$$
\begin{array}{ll}
\text { Optimistic } & : Z=Z_{P O}+Z_{C}+Z_{S O} \\
\text { Realistic } & : Z=Z_{P R}+Z_{C}+Z_{S R}
\end{array}
$$

Meanwhile, zakat potential in Indonesia (Z) using classical fiqh approach is similar to zakat on savings, which can be formulated as follows.

Optimistic $: Z=Z_{S O}$

Realistic $: Z=Z_{S R}$

\section{RESULTS AND ANALYSIS}

\subsection{Results}

This study estimates the potential of zakat in Indonesia based on two different fiqh approaches (classical and contemporary fiqh approaches), where each approach comprises two scenarios: optimistic scenario and realistic scenario. The scenarios were developed with the aim of comparing different results based on two different assumptions.

1. Estimation of Zakat Potential using Contemporary Fiqh Approach - Optimistic Scenario

A. Estimating the potential amount of professional (household) zakat $\left(Z_{P O}\right)$

Calculation of the potential of household zakat using contemporary fiqh approach under an optimistic scenario is done by multiplying the average value of zakat in each province with the number of real households per province then multiplied by the proportion of Muslim population in each province. The summation of all 34 provincial household zakat is the potential value of household zakat, as formulated in equation (2). 
Table 6.

The Potential of Professional (Household) Zakat: Optimistic Scenario

\begin{tabular}{|c|c|c|c|c|c|}
\hline PROVINCE & $\begin{array}{c}\text { Number of } \\
\text { Households } \\
\text { With Income } \\
\text { Above } \\
\text { IDR3,825,200 }\end{array}$ & $\begin{array}{c}\text { Average } \\
\text { Professional } \\
\text { (Household) } \\
\text { Zakat 1-Year } \\
\text { Sample } \\
\text { (IDR } \\
\text { Million) }\end{array}$ & $\begin{array}{l}\text { Number of } \\
\text { Households } \\
\text { (Million) }\end{array}$ & $\begin{array}{c}\text { Percentage } \\
\text { of Muslims } \\
(\%)\end{array}$ & $\begin{array}{c}\text { Professional } \\
\text { (Household) } \\
\text { Zakat Per } \\
\text { Province } \\
\text { (IDR Trillion) }\end{array}$ \\
\hline ACEH & 3,231 & 1.9 & 1.18 & 98.19 & 2.26 \\
\hline NORTH SUMATRA & 5,082 & 1.8 & 3.25 & 66.09 & 3.94 \\
\hline WEST SUMATRA & 3,645 & 2.0 & 1.23 & 97.42 & 2.43 \\
\hline RIAU & 2,995 & 2.0 & 1.52 & 87.98 & 2.68 \\
\hline JAMBI & 1,581 & 2.0 & 0.84 & 95.41 & 1.63 \\
\hline SOUTH SUMATRA & 2,294 & 1.8 & 1.95 & 96.89 & 3.52 \\
\hline BENGKULU & 1,323 & 1.9 & 0.47 & 97.29 & 0.91 \\
\hline LAMPUNG & 1,733 & 2.1 & 2.06 & 95.48 & 4.19 \\
\hline BANGKA BELITUNG & 1,851 & 1.8 & 0.34 & 89.00 & 0.58 \\
\hline KEPRI & 1,583 & 2.0 & 0.52 & 79.34 & 0.86 \\
\hline DKI JAKARTA & 2,965 & 2.9 & 2.65 & 85.36 & 6.67 \\
\hline WEST JAVA & 6,375 & 2.2 & 12.41 & 97.00 & 26.79 \\
\hline CENTRAL JAVA & 5,483 & 1.9 & 9.06 & 95.42 & 16.65 \\
\hline DI YOGYAKARTA & 1,049 & 2.1 & 1.10 & 91.95 & 2.18 \\
\hline EAST JAVA & 6,628 & 2.1 & 10.73 & 96.36 & 21.77 \\
\hline BANTEN & 2,722 & 2.3 & 2.93 & 94.67 & 6.62 \\
\hline BALI & 2,060 & 2.0 & 1.09 & 13.37 & 0.30 \\
\hline WEST NUSA TENGGARA & 1,430 & 1.9 & 1.34 & 96.47 & 2.51 \\
\hline EAST NUSA TENGGARA & 1,576 & 1.8 & 1.10 & 9.05 & 0.18 \\
\hline WEST KALIMANTAN & 2,085 & 1.9 & 1.11 & 59.22 & 1.27 \\
\hline CENTRAL KALIMANTAN & 2,670 & 1.8 & 0.64 & 74.31 & 0.89 \\
\hline SOUTH KALIMANTAN & 2,447 & 1.9 & 1.07 & 96.67 & 2.04 \\
\hline EAST KALIMANTAN & 2,611 & 2.0 & 0.85 & & 0.73 \\
\hline NORTH KALTARA & 1,154 & 2.0 & 0.14 & 85.38 & 0.12 \\
\hline NORTH SULAWESI & 2,124 & 2.0 & 0.61 & 30.90 & 0.38 \\
\hline CENTRAL SULAWESI & 1,538 & 1.9 & 0.67 & 77.72 & 1.01 \\
\hline SOUTH SULAWESI & 3,525 & 2.1 & 1.95 & 89.62 & 3.78 \\
\hline SOUTH EAST SULAWESI & 1,638 & 2.0 & 0.56 & 95.23 & 1.07 \\
\hline GORONTALO & 734 & 1.9 & 0.26 & 97.81 & 0.51 \\
\hline WEST SULAWESI & 639 & 1.9 & 0.28 & 82.66 & 0.46 \\
\hline MALUKU & 1,473 & 1.8 & 0.34 & 50.61 & 0.33 \\
\hline NORTH MALUKU & 1,273 & 1.7 & 0.24 & 74.28 & 0.31 \\
\hline WEST PAPUA & 1,627 & 1.9 & 0.19 & 38.40 & 0.14 \\
\hline PAPUA & 3,439 & 1.8 & 0.73 & 15.89 & 0.21 \\
\hline \multicolumn{5}{|c|}{ Potential of Professional Zakat $\left(Z_{p \Omega}\right)$} & 120.09 \\
\hline
\end{tabular}


Using the contemporary fiqh approach and the optimistic scenario, we thus have a total potential of professional (household) zakat of IDR 120.09 trillion, or equal to $0.97 \%$ of GDP.

B. Estimating the Potential Amount of Corporate Zakat $\left(Z_{C}\right)$

The data used to calculate the potential amount of corporate zakat were divided into two: BUMNs (State-Owned Company (SOC) and private companies. The potential amount of BUMN corporate zakat was calculated by taking the profits of all BUMN companies multiplied by the zakat rate of $2.50 \%$. The total profit of the SOC was IDR 176.177 trillion, which gave a potential BUMN corporate zakat amount of IDR 4.566 trillion.

After calculating the zakat potential of SOC, the next step is to calculate the potential amount of zakat for private companies. The Central Bureau of Statistics uses two categories for private companies: manufacturing and other private companies. Manufacturing companies refer to companies that use machines in the course of their business processes, while other private companies do not use machinery as part of their business processes. The latter include entities such as travel agents, hotels and accommodation, educational establishments, health services, and others. We also exclude companies with non-halal businesses.

The data for other private companies were in the process of being reported at the time the data for this study were collected. The researchers, therefore, used data from a previous economic census and combined it with annual economic growth data up to 2016 obtained from BPS. We used 2006 economic census data multiplied by the rate of economic growth for each year. The potential of zakat for manufacturing companies and other private companies was calculated by multiplying company profits, excluding non-halal companies, by the zakat rate of $2.50 \%$ and using the proxy rate for Muslim-owned assets of $10.97 \%$. Therefore, the total profits of POC Manufacture were IDR1,703 trillion, which gave a zakat potential of IDR4.670 trillion, while the total profits of POC Others were IDR6,413.961 trillion, which gave a zakat potential of IDR17.639 trillion.

Table 7.

The Potential of Corporate Zakat: Optimistic Scenario

\begin{tabular}{llc}
\hline No. & \multicolumn{1}{c}{ Types of Company } & $\begin{array}{c}\text { Total Zakat } \\
\text { (IDR trillion) }\end{array}$ \\
\hline 1 & State-Owned Company & 4.57 \\
2 & Private-Owned Manufacture & 4.67 \\
3 & Private-Owned Others & 17.64 \\
\hline Potential of Corporate Zakat $\left(Z_{c}\right)$ & 26.88 \\
\hline
\end{tabular}

Source: Authors' calculation

Therefore, the total potential zakat amount for companies is IDR 26.88 trillion, which is equivalent to $0.22 \%$ of GDP. 
C. Estimating the Potential Amount of Zakat on Savings

In this scenario, the potential of zakat on savings (third-party funds or deposits) is first calculated by adding data from third-party funds to that obtained for stateowned banks, BUMDs, and Islamic banks, and multiplying by the zakat rate of $2.50 \%$, based on the assumption that the three most popular banks are used by Indonesian Muslims.

Table 8.

The Potential Zakat on Savings: Optimistic Scenario

\begin{tabular}{|l|c|}
\hline \multicolumn{1}{|c|}{ Bank Category } & $\begin{array}{c}\text { Savings } \\
\text { (IDR trillion) }\end{array}$ \\
\hline Commercial Bank & $2,021.15$ \\
Regional Development Bank & 532.05 \\
Islamic Bank & 229.95 \\
Total & $2,783.17$ \\
Potential Zakat on Savings $\left(Z_{S O}\right)$ & 69.57 \\
\hline
\end{tabular}

Source: Statistik Perbankan Indonesia, calculated by authors

Taking the contemporary fiqh approach with an optimistic scenario, the potential amount of zakat on savings is IDR 69.57 trillion, equivalent to $0.56 \%$ of GDP.

Table 9.

The Zakat Potential using Contemporary Fiqh: Optimistic Scenario

\begin{tabular}{lcc}
\hline \multicolumn{1}{c}{ Variable } & $\begin{array}{c}\text { Total Zakat } \\
\text { (IDR trillion) }\end{array}$ & \% of 2016 GDP \\
\hline Professional (Household) Zakat $\left(Z_{P O}\right)$ & 120.09 & 0.968 \\
Corporate Zakat $\left(Z_{C}\right)$ & 26.88 & 0.217 \\
Zakat on Savings $\left(Z_{S O}\right)$ & 69.57 & 0.561 \\
Total Potential of Zakat $(Z)$ & 216.54 & 1.745 \\
\hline
\end{tabular}

Source : Processed from various sources

Thus, the total estimated zakat potential obtained using the contemporary fiqh approach with an optimistic scenario is IDR 216.52 trillion, equivalent to $1.75 \%$ of GDP recorded at IDR 12,406 trillion. The results for the potential amounts of zakat are in accordance with Kahf's (1989) estimation carried out using the contemporary fiqh approach, which stated that Indonesia has a zakat potential of $1.70 \%$ of GDP. This figure for the potential amount is half the size of that calculated by Firdaus et al.in 2012, which was $3.40 \%$ of GDP. This is due to differences in the assumptions used in the respective studies, especially in relation to the inclusion in the calculation of a proxy variable for Muslim assets ownership. 
2. Estimation of Zakat Potential using the Contemporary Fiqh ApproachRealistic Scenario

A. Estimating the potential of professional (household) zakat

Several differences were involved in calculating the potential zakat amounts using the contemporary fiqh approach and the realistic scenario, notably the addition of the potential muzakki variable obtained from the percentage of households with income reaching the threshold of the total household sample. The amount of potential professional (household) zakat under the contemporary fiqh approach and the realistic scenario is thus calculated by multiplying the average professional (household) zakat in each province (a) by the proportion of households reaching the nishab (b) and the number of real households (c) and the proportion of the Muslim population in each province (d). The result is IDR 34.73 trillion.

Table 10.

The Potential of Professional (Household) Zakat, Realistic Scenario

\begin{tabular}{|c|c|c|c|c|c|}
\hline \multirow[t]{2}{*}{ PROVINCE } & $\begin{array}{c}\text { Average } \\
\text { Household } \\
\text { Zakat (IDR } \\
\text { Million) } \\
\end{array}$ & $\begin{array}{c}\text { Percentage of } \\
\text { Households } \\
\text { above Nishab }\end{array}$ & $\begin{array}{l}\text { Number of } \\
\text { Households } \\
\text { (Million) }\end{array}$ & $\begin{array}{c}\text { Percentage } \\
\text { of Muslims } \\
(\%)\end{array}$ & \multirow[t]{2}{*}{$\begin{array}{l}\text { Household } \\
\text { Zakat of Each } \\
\text { Province } \\
\text { (IDR } \\
\text { Trillion) }\end{array}$} \\
\hline & (a) & (b) & (c) & (d) & \\
\hline ACEH & 1.9 & 28.91 & 1.1 & 98.19 & 0.65 \\
\hline NORTH SUMATRA & 1.8 & 27.81 & 3.2 & 66.09 & 1.09 \\
\hline WEST SUMATRA & 2.0 & 36.83 & 1.2 & 97.42 & 0.89 \\
\hline RIAU & 2.0 & 41.20 & 1.5 & 87.98 & 1.10 \\
\hline JAMBI & 2.0 & 25.94 & 0.8 & 95.41 & 0.42 \\
\hline SOUTH SUMATRA & 1.8 & 23.94 & 1.9 & 96.89 & 0.84 \\
\hline BENGKULU & 1.9 & 26.27 & 0.4 & 97.29 & 0.24 \\
\hline LAMPUNG & 2.1 & 18.93 & 2.0 & 95.48 & 0.79 \\
\hline BANGKA BELITUNG & 1.8 & 51.97 & 0.3 & 89.00 & 0.30 \\
\hline KEPRI & 2.0 & 47.51 & 0.5 & 79.34 & 0.41 \\
\hline DKI JAKARTA & 2.9 & 61.95 & 2.6 & 85.36 & 4.13 \\
\hline WEST JAVA & 2.2 & 27.70 & 12.4 & 97.00 & 7.42 \\
\hline CENTRAL JAVA & 1.9 & 20.16 & 9.6 & 95.42 & 3.35 \\
\hline DI YOGYAKARTA & 2.1 & 28.65 & 1.1 & 91.95 & 0.62 \\
\hline EAST JAVA & 2.1 & 22.49 & 10.7 & 96.36 & 4.89 \\
\hline BANTEN & 2.3 & 41.81 & 2.9 & 94.67 & 2.77 \\
\hline BALI & 2.0 & 36.04 & 1.1 & 13.37 & 0.11 \\
\hline WEST NUSA TENGGARA & 1.9 & 23.24 & 1.3 & 96.47 & 0.58 \\
\hline EAST NUSA TENGGARA & 1.8 & 14.66 & 1.1 & 9.05 & 0.02 \\
\hline WEST KALIMANTAN & 1.9 & 27.19 & 1.1 & 59.22 & 0.34 \\
\hline CENTRAL KALIMANTAN & 1.8 & 39.40 & 0.6 & 74.31 & 0.35 \\
\hline SOUTH KALIMANTAN & 1.9 & 32.88 & 1.0 & 96.67 & 0.67 \\
\hline EAST KALIMANTAN & 2.0 & 52.42 & 0.8 & & 0.38 \\
\hline NORTH KALTARA & 2.0 & 56.79 & 0.1 & 85.38 & 0.07 \\
\hline NORTH SULAWESI & 2.0 & 29.51 & 0.6 & 30.90 & 0.11 \\
\hline CENTRAL SULAWESI & 1.9 & 25.19 & 0.6 & 77.72 & 0.25 \\
\hline SOUTH SULAWESI & 2.1 & 25.85 & 1.9 & 89.62 & 0.97 \\
\hline
\end{tabular}


Table 10.

The Potential of Professional (Household) Zakat, Realistic Scenario (Continued)

\begin{tabular}{lccccc}
\hline PROVINCE & $\begin{array}{c}\text { Average } \\
\text { Household } \\
\text { Zakat (IDR } \\
\text { Million) }\end{array}$ & $\begin{array}{c}\text { Percentage of } \\
\text { Households } \\
\text { above Nishab }\end{array}$ & $\begin{array}{c}\text { Number of } \\
\text { Households } \\
\text { (Million) }\end{array}$ & $\begin{array}{c}\text { Percentage } \\
\text { of Muslims } \\
\text { (\%) }\end{array}$ & $\begin{array}{c}\text { Household } \\
\text { Zakat of Each } \\
\text { Province } \\
\text { (IDR } \\
\text { Trillion) }\end{array}$ \\
\cline { 2 - 5 } SOUTH EAST SULAWESI & $\mathbf{( a )}$ & $\mathbf{( b )}$ & $\mathbf{( c )}$ & $\mathbf{( d )}$ & 0.29 \\
GORONTALO & 2.0 & 27.35 & 0.5 & 95.23 & 0.12 \\
WEST SULAWESI & 1.9 & 24.47 & 0.2 & 97.81 & 0.10 \\
MALUKU & 1.9 & 21.89 & 0.2 & 82.66 & 0.10 \\
NORTH MALUKU & 1.8 & 30.62 & 0.3 & 50.61 & 0.09 \\
WEST PAPUA & 1.7 & 31.67 & 0.2 & 74.28 & 0.06 \\
PAPUA & 1.9 & 42.70 & 0.1 & 38.40 & 0.07 \\
\hline Potential Professional Zakat $\left(Z_{P R}\right)$ & 1.8 & 33.15 & 0.7 & 15.89 & 34.73 \\
\hline
\end{tabular}

The scenario of IDR 34.73 trillion, or $0.28 \%$ of GDP, is thus smaller than that obtained for the optimistic scenario of IDR 120.09 trillion. This is due to the reduction in the variable of the proportion of households reaching the nishab.

B. Estimating the Potential of Corporate Zakat

The potential of corporate zakat is calculated in the same way as for the optimistic scenario, which took the amount for state-owned and private companies: IDR 26.88 trillion, or $0.22 \%$ of GDP.

C. Estimating the Potential of Zakat on Savings

A different calculation was used to estimate the potential zakat on savings under the realistic scenario. The amount was calculated based on deposits from all banks in Indonesia obtained from the 2016 Indonesian Banking Statistics; thus, IDR 4,836 trillion was multiplied by $10.97 \%$ as the proxy of Muslim-owned assets in Indonesia and multiplied by the zakat rate of $2.50 \%$. The potential value of zakat on savings is, therefore, IDR 13.26 trillion, or equivalent to $0.11 \%$ of GDP. The following Table 11 contains a summary of the estimated potential zakat using the contemporary fiqh approach with the realistic scenario. 
Table 11.

The Zakat Potential using Contemporary Fiqh: Realistic Scenario

\begin{tabular}{lcc}
\hline \multicolumn{1}{c}{ Variable } & $\begin{array}{c}\text { Total Zakat } \\
\text { (IDR Trillion) }\end{array}$ & \% of 2016 GDP \\
\hline Professional (Household) Zakat $\left(Z_{P R}\right)$ & 34.73 & 0.280 \\
Corporate Zakat $\left(Z_{C}\right)$ & 26.88 & 0.217 \\
Zakat on Savings $\left(Z_{S R}\right)$ & 13.26 & 0.107 \\
Total Potential of Zakat $(Z)$ & 74.87 & 0.603 \\
\hline Source: Authors' calculation &
\end{tabular}

The result obtained from the modification of contemporary zakat under the realistic scenario is IDR74.85 trillion, or equivalent to $0.60 \%$ of Indonesia's GDP in 2016, which amounted to IDR12,406 trillion.

3. Estimation of Zakat Potential using the Classical Fiqh Approach

The zakat potential using the classical fiqh approach takes the variable of zakat on savings if savings comprise of residual income following the deduction of basic needs. Thus, based on the classical figh approach under the optimistic scenario, the zakat potential is IDR69.57 trillion, or equivalent to $0.56 \%$ of GDP, while the zakat potential based on the classical fiqh approach under the realistic scenario is IDR13.26 trillion, or equivalent to 0.11\% of GDP in 2016.

\section{Analysis}

The amount of estimated zakat potential continues to grow in line with economic development. While there are many formulations that can be used to calculate zakat potential, this study presents formulations based on the 2 (two) fiqh approaches: contemporary and classical fiqh approaches. In the contemporary fiqh approach, this study uses a basic calculation of the potential of zakat on professional (household), corporation, and savings. The study also uses a modification of 2 (two) scenarios: realistic and optimistic. The results range between $0.11 \%$ and $1.75 \%$ of the GDP.

Table 12.

Comparison of Zakat Potential Results

\begin{tabular}{llcc}
\hline No. & \multicolumn{1}{c}{ Category } & $\begin{array}{c}\text { Zakat Potential } \\
\text { (IDR Trillion) }\end{array}$ & $\begin{array}{c}\text { Percentage of } \\
\text { 2016 GDP }\end{array}$ \\
\hline 1 & Contemporary Fiqh Approach under Optimistic Scenario & 216.54 & 1.75 \\
2 & Contemporary Fiqh Approach under Realistic Scenario & 74.87 & 0.60 \\
3 & Classical Fiqh Approach under Optimistic Scenario & 69.57 & 0.56 \\
4 & Classical Fiqh Approach under Realistic Scenario & 13.26 & 0.11 \\
\hline
\end{tabular}

Source: Authors' calculation

The variation in the results obtained in this study is due to differences in the assumptions used. The optimistic scenario assumes that all Indonesian Muslims pay zakat after receiving income, as decreed by Ibn Abbas. The realistic scenario, 
meanwhile, operates on the assumption that zakat is paid only by muzakki, who tend to pay zakat. The fundamental difference in the calculations under the contemporary and classical fiqh approaches is that classical fiqh uses only thirdparty fund (deposits) variables. It assumes that the savings of Muslims are the extra assets in excess of basic needs.

In the classical fiqh approach, the optimistic and realistic scenarios use different source of data. The optimistic scenario uses data from third-party funds or deposits of 3 (three) banking groups: BUMN (state-owned bank), BUMD (regional state-owned bank), and Islamic banks. Whereas the realistic scenario uses thirdparty funds or deposits of all banks in Indonesia, multiplied by $10.97 \%$, a proxy of Muslim-owned assets in Indonesia.

Table 13.

Differences in Assumptions of the Zakat Potentialof Classical Fiqh

\begin{tabular}{|c|c|c|c|c|}
\hline No. & Category & Assumption & $\begin{array}{l}\text { Zakat Potential } \\
\text { (IDR Trillion) }\end{array}$ & $\begin{array}{c}\% \\
\text { GDP }\end{array}$ \\
\hline 1 & $\begin{array}{l}\text { Classical- } \\
\text { Optimistic } \\
\text { Scenario }\end{array}$ & $\begin{array}{l}\text { All deposits in state-owned banks, regional } \\
\text { stated-owned banks, and Islamic banks have the } \\
\text { potential to become objects of zakat. }\end{array}$ & 69.57 & 0.56 \\
\hline \multirow[b]{2}{*}{2} & \multirow[b]{2}{*}{$\begin{array}{l}\text { Classical- } \\
\text { Realistic Scenario }\end{array}$} & $\begin{array}{l}\text { All deposits in all banks have the potential to } \\
\text { become objects of zakat. }\end{array}$ & \multirow[b]{2}{*}{13.26} & \multirow[b]{2}{*}{0.11} \\
\hline & & $\begin{array}{l}\text { Multiplied by the proxy of Muslim-owned assets } \\
\left(M_{A}=10.97 \%\right) \text {, obtained from the percentage of } \\
\text { the } 8 \text { richest Muslims among the } 50 \text { richest people } \\
\text { in Indonesia in } 2016 \text {. }\end{array}$ & & \\
\hline
\end{tabular}

Source: Authors' calculation.

After comparing the results of each approach and each scenario, we undertake a comparison of the results of this study with its main reference. The difference between Firdaus et al. (2012) and contemporary optimistic scenario is essentially in the calculation of corporate zakat $\left(Z_{C}\right)$, where contemporary optimistic scenario uses proxy of Muslim-owned assets $\left(M_{A}=10.97 \%\right)$ to calculate POC zakat, resulting the estimated zakat potential being significantly lower. Moreover, contemporary realistic scenario uses different calculation in all three types of zakat. Household zakat add the percentage of muzakki or eligible household with income above the nisab (threshold) in every province $\left(M Z_{r}\right)$, corporate zakat adds $M_{A^{\prime}}$, while zakat on savings uses deposits of all banks $\left(S_{N B}\right)$ multiplied by $M_{A^{\prime}}$ resulting the zakat potential being significantly lower. 
Table 14.

Differences in Results and Assumptions with Firdaus et al. (2012)

\begin{tabular}{|c|c|c|c|c|c|c|c|}
\hline No. & Category & Assumption & $\begin{array}{r}\text { Potent } \\
\text { (IDR Tril }\end{array}$ & $\begin{array}{l}\text { ial } \\
\text { lion) }\end{array}$ & $\begin{array}{l}\text { Total } \\
\text { (IDR } \\
\text { Trillion) }\end{array}$ & $\begin{array}{l}\text { Data } \\
\text { (Year) }\end{array}$ & $\begin{array}{c}\% \\
\text { GDP } \\
(\%)\end{array}$ \\
\hline \multirow{5}{*}{1} & \multirow{5}{*}{$\begin{array}{l}\text { Zakat } \\
\text { Potential } \\
\text { According to } \\
\text { Firdaus et al. } \\
\text { (2012) }\end{array}$} & Based on the opinion of Ibn Abbas & \multirow[b]{2}{*}{$\begin{array}{c}\text { Household } \\
\text { zakat }\end{array}$} & \multirow[b]{2}{*}{82.79} & \multirow{5}{*}{217.60} & \multirow{5}{*}{2010} & \multirow{5}{*}{3.40} \\
\hline & & $\begin{array}{l}\text { Gross income is immediately } \\
\text { deducted from zakat }\end{array}$ & & & & & \\
\hline & & $\begin{array}{l}\text { Corporate zakat from profit is } \\
\text { subject to zakat rates }\end{array}$ & $\begin{array}{c}\text { Corporate } \\
\text { zakat }\end{array}$ & 117.30 & & & \\
\hline & & $\begin{array}{l}\text { Zakat on savings only takes data } \\
\text { from third-party funds of Bank and } \\
\text { Islamic Banks }\end{array}$ & \multirow[b]{2}{*}{$\begin{array}{l}\text { Zakat on } \\
\text { savings }\end{array}$} & \multirow[b]{2}{*}{17.50} & & & \\
\hline & & $\begin{array}{l}\text { The assumption is that the } \\
\text { majority of the Indonesian Muslim } \\
\text { community places excess funds in } \\
\text { these banks }\end{array}$ & & & & & \\
\hline \multirow{8}{*}{2} & \multirow{8}{*}{$\begin{array}{l}\text { Zakat } \\
\text { Potential } \\
\text { According to } \\
\text { Contemporary } \\
\text { Fiqh under } \\
\text { Optimistic } \\
\text { Scenario }\end{array}$} & Based on the opinion of Ibn Abbas & \multirow{2}{*}{$\begin{array}{c}\text { Household } \\
\text { Zakat }\end{array}$} & \multirow[b]{2}{*}{120.09} & \multirow{8}{*}{216.54} & \multirow{8}{*}{2016} & \multirow{8}{*}{1.75} \\
\hline & & $\begin{array}{l}\text { Gross income is immediately } \\
\text { deducted from zakat }\end{array}$ & & & & & \\
\hline & & $\begin{array}{l}\text { Corporate zakat multiplied by the } \\
\text { potential of muzakki }\end{array}$ & & & & & \\
\hline & & Muzakki's potential is only $10.97 \%$ & & & & & \\
\hline & & $\begin{array}{l}\text { Muzakki's potential comes from } \\
\text { data from the richest Muslim }\end{array}$ & compolate & 26.88 & & & \\
\hline & & $\begin{array}{l}\text { businessman among Indonesia's } 50 \\
\text { richest people in } 2016\end{array}$ & & & & & \\
\hline & & $\begin{array}{l}\text { Zakat on savings only takes data } \\
\text { from third-party funds of Bank and } \\
\text { Islamic Banks }\end{array}$ & \multirow[b]{2}{*}{$\begin{array}{l}\text { Zakat on } \\
\text { savings }\end{array}$} & \multirow[b]{2}{*}{69.57} & & & \\
\hline & & $\begin{array}{l}\text { The assumption is that the } \\
\text { majority of the Indonesian Muslim } \\
\text { community places excess funds in } \\
\text { these banks }\end{array}$ & & & & & \\
\hline \multirow{5}{*}{3} & \multirow{5}{*}{$\begin{array}{l}\text { Zakat } \\
\text { Potential } \\
\text { According to } \\
\text { Contemporary } \\
\text { Fiqh under } \\
\text { Realistic } \\
\text { Scenario }\end{array}$} & $\begin{array}{l}\text { Gross income is immediately } \\
\text { deducted from zakat but multiplied } \\
\text { by the potential of the household } \\
\text { zakat insurance }\end{array}$ & \multirow{2}{*}{$\begin{array}{c}\text { Household } \\
\text { zakat }\end{array}$} & \multirow{2}{*}{34.73} & \multirow{5}{*}{74.87} & \multirow{5}{*}{2016} & \multirow{5}{*}{0.60} \\
\hline & & $\begin{array}{l}\text { Muzakki's potential household zakat } \\
\text { is calculated from the percentage } \\
\text { of households with income above } \\
\text { Nishab per total sample household }\end{array}$ & & & & & \\
\hline & & $\begin{array}{l}\text { Corporate zakat is taken from } \\
\text { profits multiplied by the potential of } \\
\text { muzakki, } 10.97 \%\end{array}$ & \multirow[b]{2}{*}{$\begin{array}{l}\text { Corporate } \\
\text { zakat }\end{array}$} & \multirow[b]{2}{*}{26.88} & & & \\
\hline & & $\begin{array}{l}\text { Muzakki's potential comes from } \\
\text { data from the richest Muslim } \\
\text { businessmen among Indonesia's } 50 \\
\text { richest people in } 2016 \\
\end{array}$ & & & & & \\
\hline & & $\begin{array}{l}\text { Zakat on savings is obtained from } \\
\text { the total deposits of all banks } \\
\text { multiplied by the potential of } \\
\text { muzakki, } 10.97 \%\end{array}$ & $\begin{array}{c}\text { Zakat on } \\
\text { savings }\end{array}$ & 13.26 & & & \\
\hline
\end{tabular}


The next comparison will compare the results of this study with those of previous studies to identify differences/similarities with the results of previous studies. The result of contemporary optimistic scenario, $1.75 \%$ of GDP, resembles the results of Kahf (1989) and Wibisono (2015), in that both gave similar result of $1.70 \%$ of GDP, although all of them used different assumptions, but with similar contemporary fiqh approach. The result of contemporary realistic scenario, $0.60 \%$ of GDP, as well as the result of classical optimistic scenario, $0.56 \%$ of GDP, are both close to the results of Kahf (1989) with classical fiqf approach, 1.00\% of GDP, and UIN Syarif Hidayatullah (2005), 1.10\% of GDP, although all of them also used different assumptions. Finally, the result of classical realistic, 0.11 of GDP, has no resemblance with any previous studies. However, this result is the closest to the real 2018 zakat collection in Indonesia, $0.05 \%$ of GDP. This result could be the indication that most Indonesian Muslims follow classical fiqh approach in calculating their zakat maal obligation.

Table 15.

The Similarity of Results with Previous Research

\begin{tabular}{cccccc}
\hline No. $\begin{array}{c}\text { Current Study } \\
\text { Categories }\end{array}$ & $\begin{array}{c}\% \\
\text { GDP } \\
(\%)\end{array}$ & Prior Study & $\begin{array}{c}\% \\
\text { GDP } \\
(\%)\end{array}$ & Similarities & Differences \\
\hline
\end{tabular}

\begin{tabular}{|c|c|c|c|c|c|c|}
\hline \multirow{2}{*}{1} & \multirow{2}{*}{$\begin{array}{l}\text { Estimated } \\
\text { Zakat potential } \\
\text { according to } \\
\text { contemporary } \\
\text { fiqh under } \\
\text { the optimistic } \\
\text { scenario }\end{array}$} & \multirow{2}{*}{1.75} & Wibisono (2015) & 1.70 & $\begin{array}{l}\text { Calculates } \\
\text { zakatable } \\
\text { asset }\end{array}$ & $\begin{array}{l}\text { Wibisono calculates assets } \\
\text { based only on the economic } \\
\text { sector recorded in BPS and } \\
\text { multiplied according to their } \\
\text { respective zakat rates }\end{array}$ \\
\hline & & & $\begin{array}{l}\text { Kahf (1989); } \\
\text { Contemporary fiqh } \\
\text { approach, or Yusuf } \\
\text { Qardhawi version }\end{array}$ & 1.70 & $\begin{array}{l}\text { Calculates } \\
\text { zakat items } \\
\text { based on the } \\
\text { contemporary } \\
\text { fiqh approach }\end{array}$ & $\begin{array}{l}\text { No information on variables } \\
\text { calculated by Monzer Kahf }\end{array}$ \\
\hline \multirow[t]{2}{*}{2} & \multirow[t]{2}{*}{$\begin{array}{l}\text { Estimated } \\
\text { Zakat potential } \\
\text { according to } \\
\text { contemporary } \\
\text { fiqh under the } \\
\text { realistic scenario }\end{array}$} & \multirow[t]{2}{*}{0.60} & $\begin{array}{l}\text { Kahf } \\
(1989) ; \text { Classical } \\
\text { fiqh approach } \\
\text { or versionof the } \\
\text { majority of Islamic } \\
\text { scholars }\end{array}$ & 1.00 & $\begin{array}{l}\text { Calculates } \\
\text { potential } \\
\text { zakatable } \\
\text { assets }\end{array}$ & $\begin{array}{l}\text { Calculated the same way as } \\
\text { in Wibisono (2015). Takes the } \\
\text { economic sector as included } \\
\text { in the category of classical } \\
\text { fiqh zakat assets, then } \\
\text { multiplies according to their } \\
\text { respective rates }\end{array}$ \\
\hline & & & $\begin{array}{l}\text { UIN Syarif } \\
\text { Hidayatullah (2005) }\end{array}$ & 1.10 & $\begin{array}{l}\text { Calculates } \\
\text { zakatable } \\
\text { assets }\end{array}$ & Also calculates zakat al-Fitr \\
\hline \multirow[t]{2}{*}{3} & \multirow[t]{2}{*}{$\begin{array}{l}\text { Estimated } \\
\text { Zakat potential } \\
\text { according to } \\
\text { classical fiqh } \\
\text { under the } \\
\text { optimistic } \\
\text { scenario }\end{array}$} & \multirow[t]{2}{*}{0.56} & $\begin{array}{l}\text { Kahf } \\
(1989) ; \text { Classical } \\
\text { fiqh approach } \\
\text { or versionof the } \\
\text { majority of Islamic } \\
\text { scholars }\end{array}$ & 1.00 & $\begin{array}{l}\text { Calculates } \\
\text { potential } \\
\text { zakatable } \\
\text { assets }\end{array}$ & $\begin{array}{l}\text { The method ofcalculation } \\
\text { is the same as in Wibisono } \\
\text { (2015). Takes the economic } \\
\text { sector as included in the } \\
\text { category of classical fiqh } \\
\text { zakatable assets, then } \\
\text { multiplies according to their } \\
\text { respective rates }\end{array}$ \\
\hline & & & $\begin{array}{l}\text { UIN Syarif } \\
\text { Hidayatullah (2005) }\end{array}$ & 1.10 & $\begin{array}{l}\text { Calculates } \\
\text { zakatable } \\
\text { assets }\end{array}$ & Also calculates zakat al-Fitr \\
\hline
\end{tabular}


Table 15.

The Similarity of Results with Previous Research (Continued)

\begin{tabular}{|c|c|c|c|c|c|c|}
\hline No. & $\begin{array}{l}\text { Current Study } \\
\text { Categories }\end{array}$ & $\begin{array}{c}\% \\
\text { GDP } \\
(\%)\end{array}$ & Prior Study & $\begin{array}{c}\% \\
\text { GDP } \\
(\%)\end{array}$ & Similarities & Differences \\
\hline 4 & $\begin{array}{l}\text { Estimated } \\
\text { zakat potential } \\
\text { according to } \\
\text { classical figh } \\
\text { under the } \\
\text { realistic scenario }\end{array}$ & 0.11 & \multicolumn{4}{|c|}{ There are no similar previous studies } \\
\hline
\end{tabular}

According to BPS data, Indonesia had a GDP per capita in 2016 of IDR 47.39 million. We attempted to calculate the zakat potential based on GDP per capita with the average zakat per capita being IDR 1.1 million. We then calculated a proxy for Muslim assets ownership for the total population of Indonesian Muslims (207.177 million) by multiplying the total Muslim population by $10.97 \%$, giving a result of 22.727 million potential muzakki. Therefore, the zakat potential is IDR 25.0 trillion, equivalent to $0.19 \%$ of 2016 GDP.

We also used a proxy for muzakki. This figure is $16.00 \%$, which is obtained based on the 8 Muslims included in the list of the 50 richest people in Indonesia as published in 2016 by Forbes magazine. The total Muslim population after multiplying by the proxy for muzakki is 33 million, which gives an estimated zakat potential based on GDP per capita of IDR 36.30 trillion, or equivalent to $0.29 \%$ of the 2016 GDP. Using the approach of GDP per capita, the potential professional (household) zakat under the contemporary fiqh approach with the realistic scenario is closest to the zakat potential based on the calculation of GDP per capita, which amounted to IDR 34.73 trillion or equal to $0.27 \%$ of GDP in 2016.

It should be noted that Wibisono (2015) based the potential number of people who were eligible to pay zakat (potential muzakki) on various assumptions, with this sub-population equating to around 30\% of the total Indonesian population. Kahf's (1989) study, in contrast, did not even take into account the potential of people who pay zakat (muzakki potential). By using Forbes magazine's listing of the 50 richest people in Indonesia for 2016, the researchers in this study attempted to find a proxy that would most closely reflect the potential value of muzakki in order to reinforce the validity of the results.

Ultimately, this study demonstrated its limited data for both the professional zakat data (households), which currently uses only household consumption data obtained from population surveys, and the data for potential muzakki, which, however realistic it may be as a source, is still based on a proxy.

\section{CONCLUSION AND RECOMMENDATION}

\subsection{Conclusion}

Based on classical fiqh, zakat mal is represented by zakat on savings. Meanwhile, based on contemporary fiqh, zakat mal is represented by zakat on savings, professional (household) zakat, and corporate zakat. This study uses 
2 (two) scenarios in determining zakat potentials, both of which have different assumptions. The optimistic scenario assumes that all Muslim residents pay zakat, while the realistic scenario assumes that only rich members of the Muslim population (muzakki) pay zakat.

The results of the study show that the zakat potential calculated according to the classical fiqh approach under the optimistic scenario is IDR 69.57 trillion, or equivalent to $0.56 \%$ of GDP; under the realistic scenario, the corresponding figures are IDR 13.26 trillion, or equal to $0.11 \%$ of GDP. Meanwhile, the zakat potential based on the contemporary fiqh approach under the optimistic scenario is IDR 216.54 trillion, or equivalent to $1.75 \%$ of GDP; under the realistic scenario, the result is IDR74.87 trillion, or equal to $0.60 \%$ of GDP. The results obtained under the optimistic scenario based on the contemporary fiqh approach are approximate to those obtained by Kahf (1989) and Wibisono (2015), both of which were $1.70 \%$ of GDP.

The actual amount of zakat collected (not including infaq) in 2017 was IDR 4.19 trillion, or equal to $0.03 \%$ of GDP. This amount is closest to the potential zakat estimation that was obtained using the classical fiqh approach with the realistic scenario, which wasIDR13.26 trillion $(0.11 \%$ of GDP). This could be due to the Muslim community in Indonesia is more familiar with the classical figh approach than the contemporary fiqh approach.

\subsection{Recommendation}

The main obstacle in the research on zakat, including this research, is the difficulty in obtaining and a lack of the required data. Without the right data to support it, research on zakat becomes constrained and expensive. An integrated, comprehensive, and up-to-date zakat database is therefore needed to improve the efficiency and effectiveness of zakat management. As such, zakat authorities must prioritize the development of such database.

The results obtained from the calculation of zakat potential in Indonesia range from IDR 13.26 trillion to IDR216.54 trillion, or equal to $0.10 \%$ to $1.75 \%$ of GDP. The figures are still significantly way higher than the actual amount of zakat collected (not including infaq) for 2018, which amounted to only IDR 8.10 trillion, or $0.05 \%$ of GDP, although only 3 (three) out of a maximum of 9 (nine) legal objects of zakat were included in this study. This reinforces the ineffectiveness of zakat collection in Indonesia. Therefore, the relevant zakat authorities and zakat management organizations (OPZ) must also prioritize both an extensification and intensification of zakat collection, which remains far from its potential, in that zakat distribution programs to alleviate poverty and improve people's welfare could be improved.

The result of this study based on the contemporary fiqh approach with an optimistic scenario (1.75\% of GDP) is similar to the results obtained by Kahf (1989) and Wibisono (2015) of $1.70 \%$ of GDP. This study has also extended the research conducted by Firdaus et al. (2012). However, this study has its shortcomings, notably where the data used relies on the use of some generated proxies, indicating that real data is needed to fix it. The researchers suggest that future research should use real data on potential muzakki to avoid the use of any proxy in calculating zakat potential. In the same line, BPS should collect the necessary data in the form 
of a 10-year population census, in that subsequent studies should not have to rely on the use of arguable proxy data.

The researchers hope that this study could be used as reference by the related authorities to come up with standards and regulations in calculating zakat potentials, in that the development of zakat management could be accurately measured, especially in the accomplishment of zakat management objectives to alleviate poverty and improve wellbeing of the ummah. The results of this study could also be used by zakat management organization (OPZ) as the benchmark to improve and expand their zakat collection programs to realize the potentials. Finally, for the academics, this study could be used as reference for improved next research in this topic by improving the methods, the proxies, the approaches and the data, leading to the potential of zakat in Indonesia to be better estimated.

\section{REFERENCES}

Abdullah, N., Derus, A.M., \& Al-Malkawi, H.A.N. (2014). The Effectiveness Of Zakat In Alleviating Poverty And Inequalities: A Measurement Using Anewly Developed Technique. Humanomics, 31(3), 314-329.

Ascarya (2017). The Real Determinants of Financial Crisis and How to Resolve It in Islamic Economics Perspective. International Journal of Economic Research, 14(13).

Ascarya, Hakim, C.M., Rahmawati, S., Masrifah, A.R., Beik, I.S., Zaenal, M.H., Rizkiningsih, P., \& Choirin, M. (2018). Zakat Risk Management. Jakarta, Indonesia: Bank Indonesia - The National Board of Zakat.

Beik, I.S., \& Arsyianti, L.D. (2015). Construction of CIBEST Model As Measurement of Poverty And Welfare Indices from Islamic Perspective. Jurnal Al-Iqtishad,7(1).

Choudhury, M.A., \& Harahap, S.S. (2008).Interrelationship between Zakat, Islamic Bank and the Economy: A Theoretical Exploration. Managerial Finance, 34(9), 610-617.

Djaghballou, C.E., Djaghballou, M., Larbani, M., \& Mohamad, A. (2017). Efficiency and Productivity Performance of Zakat Funds in Algeria. International Journal of Islamic and Middle Eastern Finance and Management, 11(3), 474-494.

Firdaus, M., Beik, I.S., Irawan, T.,\& Juanda, B. (2012). Economic Estimation and Determination of Zakat Potential in Indonesia. IRTI Working Paper Series. IDB.

Hasan, M.K. (2010). An Integrated Poverty Alleviation Model Combining Zakat, Awqaf, and Micro Finance. Paper presented at the Seventh International Conference: The Tawhidi Epistemology: Zakat and Waqf Economy, ILIM, Malaysia.

Hoque, N., Khan, M.A., \& Mohammad, K.D. (2015). Poverty Alleviation by Zakah In A Transitional Economy: Asmall Business Entrepreneurial Framework. Journal of Global Entrepreneurship Research, 5(7).

Ibrahim, S. M. (2015). The Role of Zakat In Establishing Social Welfare and Economic Sustainability. International Journal of Management and Commerce Innovations, 3(1), 437-441.

Javaid, S.,\& Al-Malkawi,H.A.N. (2017). Corporate Social Responsibility and Financial Performance In Saudi Arabia: Evidence From Zakat Contribution. Managerial Finance, 44(6), 648-664. 
Kahf, M. (1989).Zakat Estimation In some Muslim Countries. Unpublished Manuscript. Kashif, M., Jamal, K.J., \& Rehman, M.A. (2016). The Dynamics of Zakat Donation Experience Among Muslims: A Phenomenological Inquiry. Journal of Islamic Accounting and Business Research, 9(1), 45-58.

Mohsin, M. I. A. (2013). Potential of Zakat In Eliminating Riba and Eradicating Poverty in Muslim countries. Co-published with Center for Research on Islamic Management and Business (CRIMB).

Obaidullah, M. (2014). Revisiting Estimation Methods of Business Zakat and Related Tax Incentives. Journal of Islamic Accounting and Business Research, 7(4), 349-364.

Parisi, S.A. (2017). Overview of Forecasting Zakat Collection In Indonesia using Multiplicative Decomposition. International Journal of Zakat, 2(1), 45-59.

PIRAC (2007). Meningkat, Kesadaran dan Kapasitas Masyarakat dalam Berzakat. Press Release.

Qardhawi, Y. (1991). Hukum Zakat di Terjemahkan oleh Dr. Salman Harun dkk. Jakarta: Pustaka Litera Antarnusa.

Saleh, Darwin Zahedy, 2013, Potret Dhuafa Perekonomian Indonesia dalam Statistik, Ide \& Terapan, Jakarts, Expose.

Samad, A.,\&Glenn, L.M. (2010). Development of Zakah and Zakah Coverage in Monotheistic Faiths. International Journal of Social Economics, 37(4), 302-315.

Sarea, A. M.(2012). Zakat as a Benchmark to Evaluate Economic Growth: An Alternative Approach. International Journal of Business and Social Science, 3(18), 242-245.

Sarwat, A.(2016). Seri Fiqih Kehidupan: Zakat. Jakarta: Rumah Fiqih Publishing.

Wahab, N.A., Zainol, Z., \& Bakar, M.A. (2017). Towards Developing Service Quality Index for Zakat Institutions. Journal of Islamic Accounting and Business Research, 8(3).doi: 10.1108/JIABR-09-2015-0040

Wibisono, Y. (2015). Mengelola Zakat Indonesia. Jakarta. Prenadamedia.

Yusuf, M.B.O., \& Derus, A.M. (2013). Measurement Model of Corporate Zakat Collection in Malaysia: A Test of Diffusion of Innovation Theory. Humanomics, 29(1), 61-74. 


\section{Appendix}

\section{Zakat of State-Owned Companies (IDR million)}

\begin{tabular}{|c|c|c|c|}
\hline No & Name of Companies & Profit & Zakat \\
\hline 1 & Perum Perhutani & $-357,317$ & 0.00 \\
\hline 2 & Perum Perikanan Indonesia & 22,207 & 555 \\
\hline 3 & PT Rajawali Nusantara Indonesia (Persero) & 246,924 & 6,173 \\
\hline 4 & PT Perikanan Nusantara (Persero) & 5,456 & 136 \\
\hline 5 & PT Perkebunan Nusantara III (Persero) & $-1,386,596$ & 0.00 \\
\hline 6 & Perum Bulog & 913,033 & 22,825 \\
\hline 7 & Perum Jasa Tirta I & 120,679 & 3,016 \\
\hline 8 & Perum Jasa Tirta II & 170,645 & 4,266 \\
\hline 9 & PT Pupuk Indonesia (Persero) & $3,525,940$ & 88,148 \\
\hline 10 & PT BioFarma (Persero) & 501,041 & 12,526 \\
\hline 11 & PT Kimia Farma (Persero) Tbk & 271,598 & 6,789 \\
\hline 12 & PT PP Berdikari (Persero) & $-79,639$ & 0.00 \\
\hline 13 & PT Sang Hyang Seri (Persero) & $-61,609$ & 0.00 \\
\hline 14 & PT Pertani (Persero) & 5,516 & 137 \\
\hline 15 & PT Garam (Persero) & 53,683 & 1,342 \\
\hline 16 & PT Indofarma (Persero) Tbk & $-17,367$ & 0.00 \\
\hline 17 & PT Pertamina (Persero) & $42,085,436$ & $1,052,135$ \\
\hline 18 & PT TWC BP dan RB (Persero) & 74,774 & 1,869 \\
\hline 19 & PT Energy Management Indonesia (Persero) & $-13,455$ & 0.00 \\
\hline 20 & PT Hotel Indonesia Natour (Persero) & $-89,228$ & 0.00 \\
\hline 21 & PT Pengembangan Pariwisata Indonesia (Persero) & 80,676 & 2,016 \\
\hline 22 & PT Perusahaan Gas Negara (Persero) Tbk & $4,106,326$ & 102,658 \\
\hline 23 & PT Sarinah (Persero) & 11,301 & 282 \\
\hline 24 & PT Perusahaan Perdagangan Indonesia (Persero) & 442,408 & 11,060 \\
\hline 25 & PT Bhanda Ghara Reksa (Persero) & 50,218 & 1,255 \\
\hline 26 & PT Pos Indonesia (Persero) & 203,276 & 5,081 \\
\hline 27 & PT Perusahaan Listrik Negara (Persero) & $10,548,638$ & 263,715 \\
\hline 28 & PT Kawasan Berikat Nusantara (Persero) & 138,295 & 3,457 \\
\hline 29 & PT Kawasan Industri Wijayakusuma (Persero) & 45,610 & 1,140 \\
\hline 30 & PT Kawasan Industri Medan (Persero) & 36,196 & 904 \\
\hline 31 & PT Kawasan Industri Makassar (Persero) & 13,546 & 338 \\
\hline 32 & Perum Percetakan Negara Republik Indonesia & 4,567 & 114 \\
\hline 33 & Perum Percetakan Uang Republik Indonesia & 160,981 & 4,024 \\
\hline 34 & Perum Produksi Film Negara & -745 & 0.00 \\
\hline 35 & Perum Lembaga Kantor Berita Nasional Antara & 9,167 & 229 \\
\hline 36 & PT Semen Indonesia (Persero) Tbk & $4,535,036$ & 113,375 \\
\hline 37 & PT Semen Baturaja (Persero) Tbk & 259,090 & 6,477 \\
\hline 38 & PT Semen Kupang (Persero) & 6,411 & 160 \\
\hline 39 & PT Tambang Batubara Bukit Asam (Persero) Tbk & $2,024,405$ & 50,610 \\
\hline 40 & PT Timah (Persero) Tbk & 251,969 & 6,299 \\
\hline 41 & PT Aneka Tambang (Persero) Tbk & 64,806 & 1,620 \\
\hline 42 & PT Balai Pustaka (Persero) & $-5,913$ & 0.00 \\
\hline 43 & PT Telekomunikasi Indonesia (Persero) Tbk & $29,172,000$ & 729,300 \\
\hline
\end{tabular}




\begin{tabular}{|c|c|c|c|}
\hline No & Name of Companies & Profit & Zakat \\
\hline 44 & PT PAL Indonesia (Persero) & $-395,225,528$ & 0.00 \\
\hline 45 & PT Industri Kapal Indonesia (Persero) & 16,171 & 404 \\
\hline 46 & PT Dok dan Perkapalan Kodja Bahari (Persero) & $-129,615$ & 0.00 \\
\hline 47 & PT Dok dan Perkapalan Surabaya (Persero) & $-81,537$ & 0.00 \\
\hline 48 & PT Indonesia Asahan Aluminium (Persero) & 884,129 & 22,103 \\
\hline 49 & PT Krakatau Steel (Persero) Tbk & $-2,404,894$ & 0.00 \\
\hline 50 & PT Boma Bisma Indra (Persero) & $-9,704$ & 0.00 \\
\hline 51 & PT Industri Nuklir Indonesia (Persero) & 557 & 13 \\
\hline 52 & PT Industri Telekomunikasi Indonesia (Persero) & $-316,198$ & 0.00 \\
\hline 53 & PT Barata Indonesia (Persero) & 20,252 & 506 \\
\hline 54 & PT Dahana (Persero) & 82,100 & 2,052 \\
\hline 55 & PT LEN Industri (Persero) & 4,822 & 120 \\
\hline 56 & PT Pindad (Persero) & 45,792 & 1,144 \\
\hline 57 & PT Dirgantara Indonesia (Persero) & $-268,604$ & 0.00 \\
\hline 58 & PT Adhi Karya (Persero) Tbk & 315,108 & 7,877 \\
\hline 59 & PT Amarta Karya (Persero) & $-138,047$ & 0.00 \\
\hline 60 & PT Brantas Abipraya (Persero) & 178,255 & 4,456 \\
\hline 61 & PT Jasa Marga (Persero) Tbk & $1,803,054$ & 45,076 \\
\hline 62 & PT Waskita Karya (Persero) Tbk & $1,813,068$ & 45,326 \\
\hline 63 & PT Wijaya Karya (Persero) Tbk & $1,147,145$ & 28,678 \\
\hline 64 & PT Hutama Karya (Persero) & 301,764 & 7,544 \\
\hline 65 & PT Pembangunan Perumahan (Persero) Tbk & $1,151,432$ & 28,78 \\
\hline 66 & Perum Perumnas & 93,022 & 2,325 \\
\hline 67 & PT Industri Kereta Api (Persero) & 44,750 & 1,118 \\
\hline 68 & PT PDI Pulau Batam (Persero) & 4,758 & 118 \\
\hline 69 & PT Pelabuhan Indonesia I (Persero) & 733,302 & 18,332 \\
\hline 70 & PT Pelabuhan Indonesia II (Persero) & $1,537,215$ & 38,43 \\
\hline 71 & PT Pelabuhan Indonesia III (Persero) & $1,512,317$ & 37,807 \\
\hline 72 & PT Pelabuhan Indonesia IV (Persero) & 330,260 & 8,256 \\
\hline 73 & PT Indah Karya (Persero) & 13,709 & 342 \\
\hline 74 & PT Bina Karya (Persero) & 6,293 & 157 \\
\hline 75 & Perum Damri & 40,643 & 1,016 \\
\hline 76 & Perum Pengangkutan Penumpang Djakarta & 9,736 & 243 \\
\hline 77 & $\begin{array}{l}\text { Perum Lembaga Penyelenggara Pelayanan Navigasi } \\
\text { Penerbangan Indonesia }\end{array}$ & 418,733 & 10,468 \\
\hline 78 & PT Angkasa Pura I (Persero) & $1,159,577$ & 28,989 \\
\hline 79 & PT Angkasa Pura II (Persero) & $1,940,254$ & 48,506 \\
\hline 80 & PT Virama Karya (Persero) & $-23,106$ & 0.00 \\
\hline 81 & PT Yodya Karya (Persero) & 21,529 & 538 \\
\hline 82 & PT Indra Karya (Persero) & $-4,356$ & 0.00 \\
\hline 83 & PT Bank Negara Indonesia (Persero) Tbk & $11,410,196$ & 285,254 \\
\hline 84 & PT Bank Mandiri (Persero) Tbk & $14,650,163$ & 366,254 \\
\hline 85 & PT Bank Rakyat Indonesia (Persero) Tbk & $26,227,991$ & 655,699 \\
\hline 86 & PT Bank Tabungan Negara (Persero) Tbk & $2,618,905$ & 65,472 \\
\hline 87 & Perum Jaminan Kredit Indonesia & 692,045 & 17,301 \\
\hline 88 & PT ASABRI (Persero) & 537,628 & 13,440 \\
\hline
\end{tabular}




\begin{tabular}{llcc}
\hline No & \multicolumn{1}{c}{ Name of Companies } & Profit & Zakat \\
\hline 89 & PT Asuransi Jasa Indonesia (Persero) & 366,412 & 9,160 \\
90 & PT Asuransi Jiwasraya (Persero) & $1,722,821$ & 43,070 \\
91 & PT Asuransi Kredit Indonesia (Persero) & 907,863 & 22,696 \\
92 & PT Jasa Raharja (Persero) & $2,376,956$ & 59,423 \\
93 & PT Reasuransi Indonesia Utama (Persero) & 266,102 & 6,652 \\
94 & PT Taspen (Persero) & 247,253 & 6,181 \\
95 & PT Garuda Indonesia (Persero) Tbk & 124,618 & 3,115 \\
96 & PT Pelayaran Nasional Indonesia (Persero) & 248,402 & 6,210 \\
97 & PT Kereta Api Indonesia (Persero) & $1,018,240$ & 25,456 \\
98 & PT Bahana Pembinaan Usaha Indonesia (Persero) & 129,914 & 3,247 \\
99 & PT Biro Klasifikasi Indonesia (Persero) & 67,613 & 1,690 \\
100 & PT Danareksa (Persero) & 116,258 & 2,906 \\
101 & PT Kliring Berjangka Indonesia (Persero) & 11,629 & 290 \\
102 & PT Permodalan Nasional Madani (Persero) & 77,017 & 1,925 \\
103 & PT PANN (Persero) & $-559,929$ & 0.00 \\
104 & PT Pegadaian (Persero) & $2,210,252$ & 55,256 \\
105 & PT Sucofindo (Persero) & 148,344 & 3,708 \\
106 & PT Surveyor Indonesia (Persero) & 89,803 & 2,245 \\
107 & PT ASDP Indonesia Ferry (Persero) & 233,413 & 5,835 \\
108 & PT Djakarta Lloyd (Persero) & 29,935 & 748 \\
109 & PT Perusahaan Pengelola Aset (Persero) & 281,266 & 7,031 \\
110 & PT Iglas (Persero) & $-53,103$ & 0.00 \\
111 & PT Industri Sandang Nusantara (Persero) & $-53,101$ & 0.00 \\
112 & PT Istaka Karya (Persero) & 28,810 & 720 \\
113 & PT Primissima (Persero) & 12,482 & 312 \\
114 & PT Survai Udara Penas (Persero) & $-18,590$ & 0.00 \\
115 & PT Varuna Tirta Prakasya (Persero) & 768 & 19 \\
116 & PT Kertas Kraft Aceh (Persero) & 0.00 & 0.00 \\
117 & PT Kertas Leces (Persero) & 0.00 & 0.00 \\
118 & PT Merpati Nusantara Airlines (Persero) & 0.00 \\
\hline TOTAL & & $\mathbf{1 7 6}, 00,176,838$ \\
\hline
\end{tabular}

Source: The Ministry of State Owned Enterprises

Zakat of Manufacturing Private Companies (IDR trillion)

\begin{tabular}{lccc}
\hline & \multicolumn{2}{c}{ Sector } & 2016 (Growth 5,02\%) \\
\hline Food Product & 22.9 & & \\
Beverages & -9.4 & & \\
Liquors & -0.2 & & \\
Wine & & 0.6 & 13 \\
Total & & 4.2 & 93 \\
Textiles & 2.8 & 58 \\
Wearing apparel & & 1.5 & 37 \\
Tanning and dressing of leather & & 1.1 & 24 \\
Wood, products of wood & & 1.1 & \\
Except for furniture & &
\end{tabular}




\begin{tabular}{lcc}
\hline \multicolumn{1}{c}{ Sector } & 2016 (Growth $\mathbf{5 , 0 2} \%$ ) \\
\hline Paper and paper products & 3.4 & 64 \\
Publishing, printing and reproduction ofrecorded media & 0.6 & 13 \\
Coal, refined petroleum products and nuclear fuel & 0.1 & 2 \\
Chemicals and chemical products & 11.1 & 232 \\
Pharmacy and medicine & 0.8 & 16 \\
Rubber and plastics products & 7.2 & 150 \\
Glass & 4.1 & 86 \\
Basic metal & 3.5 & 74 \\
Fabricated metal products, except machinery and equipment & 2.1 & 45 \\
Electron tube and connector electric & 2.0 & 42 \\
Electrical machinery andapparatus n.e.c & 3.7 & 78 \\
Machinery and equipment n.e. & 1.7 & 37 \\
Motor vehicles, trailers and semi-trailers & 7.8 & 163 \\
Other transport equipment & 3.0 & 63 \\
Furniture and manufacturing n.e.c & 1.1 & 24 \\
Jewellery and other valuable goods & 0.8 & 17 \\
Recycling & 0.1 & 3 \\
Total & 81.4 & $\mathbf{1 , 7 0 3}$ \\
Zakat & & 4.670 \\
\hline Source:BPS (processed)
\end{tabular}

\section{Zakat of Other Private Companies (billion IDR)}

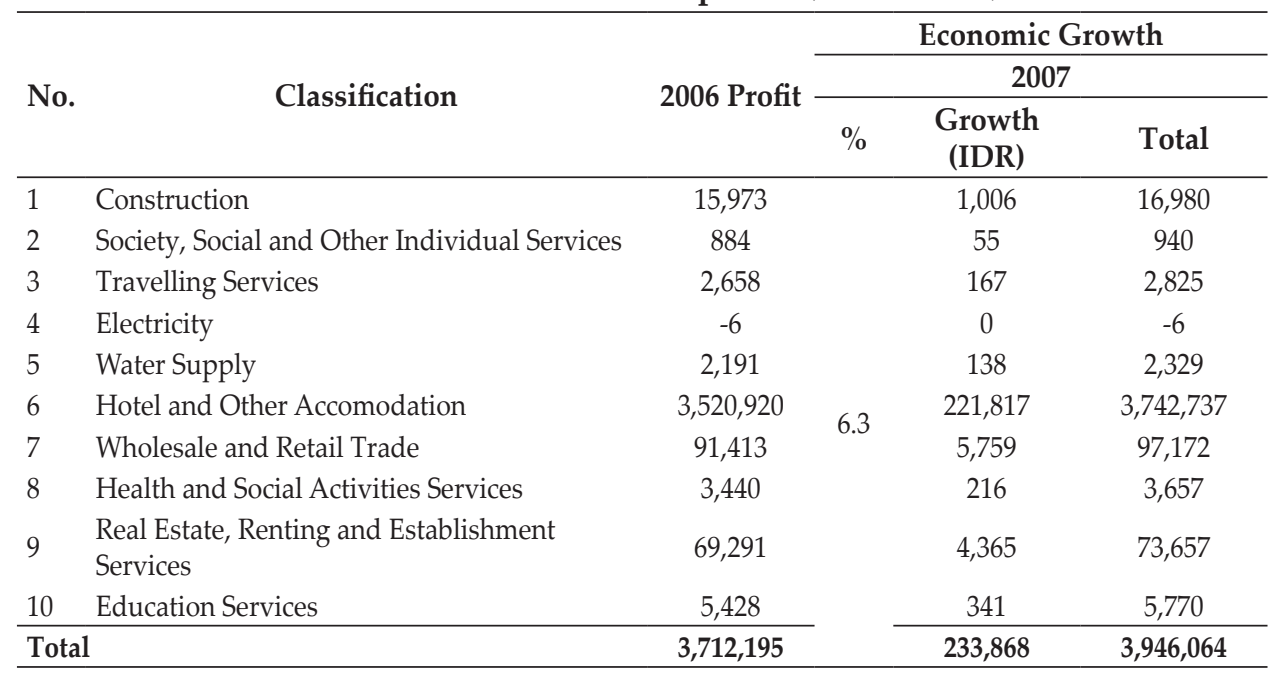




\begin{tabular}{|c|c|c|c|c|c|}
\hline \multirow{3}{*}{ No. } & \multirow{3}{*}{ Classification } & \multirow{3}{*}{2007} & \multicolumn{3}{|c|}{ Economic Growth } \\
\hline & & & \multicolumn{3}{|c|}{2008} \\
\hline & & & $\%$ & $\begin{array}{l}\text { Growth } \\
\text { (IDR) }\end{array}$ & Total \\
\hline 1 & Construction & 16,980 & \multirow{11}{*}{6.1} & 1,035 & 18,016 \\
\hline 2 & Society, Social and Other Individual Services & 940 & & 57 & 997 \\
\hline 3 & Travelling Services & 2,825 & & 172 & 2,998 \\
\hline 4 & Electricity & -6 & & 0 & -6 \\
\hline 5 & Water Supply & 2,329 & & 142 & 2,471 \\
\hline 6 & Hotel and Other Accomodation & $3,742,737$ & & 228,307 & $3,971,044$ \\
\hline 7 & Wholesale and Retail Trade & 97,172 & & 5,927 & 103,099 \\
\hline 8 & Health and Social Activities Services & 3,657 & & 223 & 3,880 \\
\hline 9 & $\begin{array}{l}\text { Real Estate, Renting and Establishment } \\
\text { Services }\end{array}$ & 73,657 & & 4,493 & 78,150 \\
\hline 10 & Education Services & 5,770 & & 351 & 6,122 \\
\hline \multicolumn{2}{|c|}{ Total } & $3,946,064$ & & 240,709 & $4,186,774$ \\
\hline \multirow{3}{*}{ No. } & \multirow{3}{*}{ Classification } & \multirow{3}{*}{2008} & \multicolumn{3}{|c|}{ Economic Growth } \\
\hline & & & \multicolumn{3}{|c|}{2009} \\
\hline & & & $\%$ & $\begin{array}{l}\text { Growth } \\
\text { (IDR) }\end{array}$ & Total \\
\hline 1 & Construction & 18,016 & \multirow{11}{*}{4.5} & 810 & 18,826 \\
\hline 2 & Society, Social and Other Individual Services & 997 & & 44 & 1,042 \\
\hline 3 & Travelling Services & 2,998 & & 134 & 3,133 \\
\hline 4 & Electricity & -6 & & 0 & -6 \\
\hline 5 & Water Supply & 2,471 & & 111 & 2,582 \\
\hline 6 & Hotel and Other Accomodation & $3,971,044$ & & 178,697 & $4,149,742$ \\
\hline 7 & Wholesale and Retail Trade & 103,099 & & 4,639 & 107,739 \\
\hline 8 & Health and Social Activities Services & 3,880 & & 174 & 4,055 \\
\hline 9 & $\begin{array}{l}\text { Real Estate, Renting and Establishment } \\
\text { Services }\end{array}$ & 78,150 & & 3,516 & 81,667 \\
\hline 10 & Education Services & 6,122 & & 275 & 6,397 \\
\hline \multicolumn{2}{|c|}{ Total } & $4,186,774$ & & 188,404 & $4,375,178$ \\
\hline \multirow{3}{*}{ No. } & \multirow{3}{*}{ Classification } & \multirow{3}{*}{2009} & \multicolumn{3}{|c|}{ Economic Growth } \\
\hline & & & \multicolumn{3}{|c|}{2010} \\
\hline & & & $\%$ & $\begin{array}{c}\text { Growth } \\
\text { (IDR) }\end{array}$ & Total \\
\hline 1 & Construction & 18,826 & \multirow{11}{*}{6.1} & 1,148 & 19,975 \\
\hline 2 & Society, Social and Other Individual Services & 1,042 & & 63 & 1,106 \\
\hline 3 & Travelling Services & 3,133 & & 191 & 3,324 \\
\hline 4 & Electricity & -6 & & 0 & -6 \\
\hline 5 & Water Supply & 2,582 & & 157 & 2,740 \\
\hline 6 & Hotel and Other Accomodation & $4,149,742$ & & 253,134 & $4,402,876$ \\
\hline 7 & Wholesale and Retail Trade & 107,739 & & 6,572 & 114,311 \\
\hline 8 & Health and Social Activities Services & 4,055 & & 247 & 4,302 \\
\hline 9 & $\begin{array}{l}\text { Real Estate, Renting and Establishment } \\
\text { Services }\end{array}$ & 81,667 & & 4,981 & 86,648 \\
\hline 10 & Education Services & 6,397 & & 390 & 6,788 \\
\hline \multicolumn{2}{|c|}{ Total } & $4,375,178$ & & 266,885 & $4,642,064$ \\
\hline
\end{tabular}




\begin{tabular}{|c|c|c|c|c|c|}
\hline \multirow{3}{*}{ No. } & \multirow{3}{*}{ Classification } & \multirow{3}{*}{2010} & \multicolumn{3}{|c|}{ Economic Growth } \\
\hline & & & \multicolumn{3}{|c|}{2011} \\
\hline & & & $\%$ & $\begin{array}{c}\text { Growth } \\
\text { (IDR) }\end{array}$ & Total \\
\hline 1 & Construction & 19,975 & \multirow{11}{*}{6.5} & 1,298 & 21,273 \\
\hline 2 & Society, Social and Other Individual Services & 1,106 & & 71 & 1,178 \\
\hline 3 & Travelling Services & 3,324 & & 216 & 3,540 \\
\hline 4 & Electricity & -6 & & 0 & -6 \\
\hline 5 & Water Supply & 2,740 & & 178 & 2,918 \\
\hline 6 & Hotel and Other Accomodation & $4,402,876$ & & 286,186 & $4,689,063$ \\
\hline 7 & Wholesale and Retail Trade & 114,311 & & 7,430 & 121,741 \\
\hline 8 & Health and Social Activities Services & 4,302 & & 279 & 4,582 \\
\hline 9 & $\begin{array}{l}\text { Real Estate, Renting and Establishment } \\
\text { Services }\end{array}$ & 86,648 & & 5,632 & 92,281 \\
\hline 10 & Education Services & 6,788 & & 441 & 7,229 \\
\hline \multicolumn{2}{|c|}{ Total } & $4,642,064$ & & 301,734 & $4,943,799$ \\
\hline \multirow{3}{*}{ No. } & \multirow{3}{*}{ Classification } & \multirow{3}{*}{2011} & \multicolumn{3}{|c|}{ Economic Growth } \\
\hline & & & \multicolumn{3}{|c|}{2012} \\
\hline & & & $\%$ & $\begin{array}{c}\text { Growth } \\
\text { (IDR) }\end{array}$ & Total \\
\hline 1 & Construction & 21,273 & \multirow{11}{*}{6.23} & 1,325 & 22,598 \\
\hline 2 & Society, Social and Other Individual Services & 1,178 & & 73 & 1,251 \\
\hline 3 & Travelling Services & 3,540 & & 220 & 3,760 \\
\hline 4 & Electricity & -6 & & 0 & -6 \\
\hline 5 & Water Supply & 2,918 & & 181 & 3,100 \\
\hline 6 & Hotel and Other Accomodation & $4,689,063$ & & 292,128 & $4,981,191$ \\
\hline 7 & Wholesale and Retail Trade & 121,741 & & 7,584 & 129,326 \\
\hline 8 & Health and Social Activities Services & 4,582 & & 285 & 4,867 \\
\hline 9 & $\begin{array}{l}\text { Real Estate, Renting and Establishment } \\
\text { Services }\end{array}$ & 92,281 & & 5,749 & 98,030 \\
\hline 10 & Education Services & 7,229 & & 450 & 7,679 \\
\hline \multicolumn{2}{|c|}{ Total } & $4,943,799$ & & 307,998 & $5,251,797$ \\
\hline \multirow{3}{*}{ No. } & \multirow{3}{*}{ Classification } & \multirow{3}{*}{2012} & \multicolumn{3}{|c|}{ Economic Growth } \\
\hline & & & \multicolumn{3}{|c|}{2013} \\
\hline & & & $\%$ & $\begin{array}{c}\text { Growth } \\
\text { (IDR) }\end{array}$ & Total \\
\hline 1 & Construction & 22,598 & \multirow{11}{*}{5.58} & 1,261 & 23,859 \\
\hline 2 & Society, Social and Other Individual Services & 1,251 & & 69 & 1,321 \\
\hline 3 & Travelling Services & 3,760 & & 209 & 3,970 \\
\hline 4 & Electricity & -6 & & 0 & -6 \\
\hline 5 & Water Supply & 3,100 & & 173 & 3,273 \\
\hline 6 & Hotel and Other Accomodation & $4,981,191$ & & 277,950 & $5,259,142$ \\
\hline 7 & Wholesale and Retail Trade & 129,326 & & 7,216 & 136,542 \\
\hline 8 & Health and Social Activities Services & 4,867 & & 271 & 5,139 \\
\hline 9 & $\begin{array}{l}\text { Real Estate, Renting and Establishment } \\
\text { Services }\end{array}$ & 98,030 & & 5,470 & 103,500 \\
\hline 10 & Education Services & 7,679 & & 428 & 8,108 \\
\hline \multicolumn{2}{|c|}{ Total } & $5,251,797$ & & 293,050 & $5,544,848$ \\
\hline
\end{tabular}




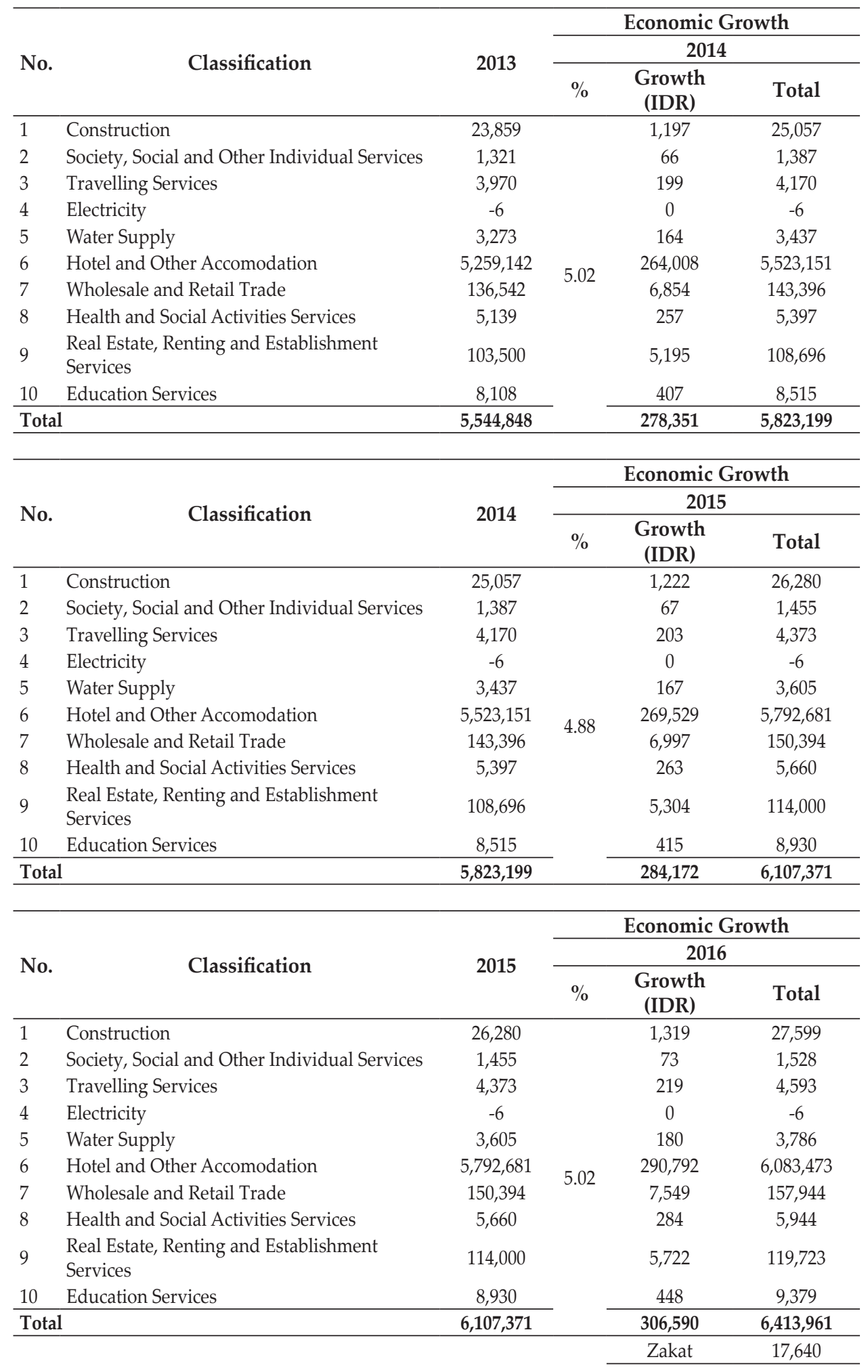


This page is intentionally left blank 